\title{
A nemzeti kisebbségek jogainak érvényesülése a román alkotmánybírósági esetgyakorlatban*
}

\section{VARGA ATTILA}

A nemzeti kisebbségek jogainak alkotmányos szabályozása három megközelítésben történik: részben az alapelvek, részben mint alapvetö emberi jogok, részben pedig mint az államszervezetet érintö szabályozások jelennek meg Románia alkotmányában.

Az alkotmányi rendelkezéseken túlmenöen, létrejöttek a nemzeti kisebbségekhez tartozó személyek jogaira vonatkozó törvényi szintü szabályozások, amelyek a legtöbb esetben alkotmányossági ellenörzés tárgyát is képezték, az alkotmánybíróság határozatai pedig meghatározták, pontositották a nemzeti kisebbségek jogainak tartalmát, értelmét, alkalmazási kereteit.

Jelen tanulmány összefoglalóan mutatja be a nemzeti kisebbségek jogaira vonatkozó alkotmányi rendelkezéseket, a román alkotmánybíróságot, hatásköreit, valamint a Taláros Testületnek a nemzeti kisebbségekre vonatkozó legfontosabb határozatait, esetgyakorlatát.

Kulcsszavak: nemzeti kisebbségek jogai, alkotmányszabályozások, alkotmánybíróság, alkotmánybírósági esetgyakorlat, bírói aktivizmus, textualizmus, kisebbségvédelem, identitás, anyanyelvhasználat.

\section{The Emergence of the Rights of National Minorities in the Case Law of the Constitutional Court of Romania}

The constitutional provisions concerning national minorities are listed in triple perspective in the Constitution of Romania, namely as fundamental principles, fundamental rights and part of the organisation of the state.

In addition to the constitutional provisions, there have been enacted provisions having the force of law that regards the rights of the persons belonging to national minorities. These laws or parts of them - in most of the cases - have been under constitutional review and in this context the Constitutional Court decisions defined and pointed out the significance and the sphere of applicability of the rights of national minorities.

This study presents the constitutional provisions regarding the rights of national minorities, the Constitutional Court of Romania, its constitutional powers and its relevant case law developed in the aforementioned field.

Keywords: rights of the national minorities, constitutional provisions, Constitutional Court, case law of the Constitutional Court, judicial activism, textualism, protection of national minorities, identity, use of mother tongue

A kutatás az Igazságügyi Minisztérium jogászképzés színvonalának emelését célzó programjai keretében valósult meg. 


\section{Bevezetés}

A román jogrendszerben az elmúlt közel 30 évben, az alkotmány és a többi jogszabályok szintjén létrejött egy a nemzeti kisebbségekre vonatkozó jogi, szabályozási keret, amely kialakulásakor és alakulásakor sok vitát, helyenként ellenállást eredményezett. Egy jó ideje pedig mondhatni stagnáló állapotba került a jogalkotás tekintetében, a jogalkalmazás során a nehezen meghozott törvényi rendelkezések betartása és alkalmazása időről időre, jobb sorsra érdemes következetességgel rendszeres akadályokba ütközik a legkülönbözőbb közhatóságok részéről.

A nemzeti kisebbségek jogainak alkotmányos szabályozása részben az alapelvek szintjén, részben mint alapvető emberi jogok, részben pedig mint az államszervezetet érintő szabályozások jelennek meg a román alaptörvényben.

Ugyanakkor értelemszerűen az alkotmányi szabályozásokon és rendelkezéseken túlmenően kialakult a nemzeti kisebbségek jogaira vonatkozó törvényi szabályozás is, amelyek a legtöbb esetben alkotmányossági felülvizsgálat tárgyát képezték az alkotmánybíróság előtt. Ez utóbbiak pedig sok esetben meghatározták, pontosították a nemzeti kisebbségek jogainak tartalmát, értelmét alkalmazási keretét.

Tanulmányomban azt vizsgálom, hogy a román alkotmánybíróság (a továbbiakban: $A B$ ) esetgyakorlatában miként viszonyult a nemzeti kisebbségek jogaihoz, menynyiben értelmezte kreatív, aktív módon a vonatkozó alkotmányi rendelkezéseket, avagy mennyire maradt az alkotmányos szövegek szigorú őrzőjének.

A nemzeti kisebbségek, így a romániai nemzetiségek, közösségek léte, pontosabban létük jogi kerete, szabályozása szempontjából megkülönböztetjük egyrészt a normatív szabályozást, a létrejött, kialakított alkotmányi és törvényi (jogszabályi) keretet és a legszélesebb értelemben vett jogalkalmazást, azaz a meglévő jogszabályok közigazgatási/hatósági és igazságszolgáltatási/bírósági alkalmazását.

E két szint, illetve dimenzió között, a kettő kölcsönhatásában, valamint a két területet meghatározó módon befolyásolva helyezkedik el az alkotmánybírósági joggyakorlat, amely egyaránt kihat a törvényhozásra, a jogalkotásra és a jogalkalmazásra.

Eddigi elemzések vizsgálták a nemzeti kisebbségekre vonatkozó jogszabályi hátteret, sokszor meglehetősen különbözőképpen, eltérő módon értékelve és értelmezve azt. Másrészt pedig voltak/vannak általánosabb vagy kifejezetten esetek kapcsán megfogalmazott elemzések a kisebbségi jogok alkalmazásával kapcsolatosan is.

Kimondottan az alkotmánybírósági esetgyakorlatra vonatkozó vagy magának a Taláros Testületnek a nemzeti kisebbségek jogaihoz való viszonyulását vizsgáló tanulmány azonban nem készült Romániában.

Jelen tanulmány éppen ezt a hiányt igyekszik bizonyos mértékben pótolni.

A jogszabályi keretet illető megosztott, eltérő vélemények azon két szélső álláspont között feszülnek, hogy egyfelől, és különösen a nemzeti kisebbségek, elsősorban a magyar nemzeti közösség szakemberei azt állítják, lényegében teljesen megalapozottan, hogy a jogszabályi keret nem megfelelő, jelentős mértékben bővítésre szorul, 
úgy a jogok, mint azok gyakorlásának garanciarendszere vonatkozásában. ${ }^{1}$ Másfelől a hivatalosnak tekinthető politikai, és a nem hivatalos szakirodalmi/szakmai álláspont szerint Románia a nemzeti kisebbségek jogainak biztosítása vonatkozásában modellértékű szabályrendszert alkotott, jelentősen meghaladva az európai jogi standardot. ${ }^{2}$ A tárgyilagos, a megfogalmazott kritikákban is korrekt román tudományos szakirodalmi hozzáállás elenyészően csekély, különösen, ha a nemzeti kisebbségek jogainak biztosításáról, e jogok kollektív dimenziójáról vagy az autonómiaformákról beszélünk. ${ }^{3}$

Kétségtelen, hogy vannak jelentős, a nemzeti kisebbségek számára rendkívül fontos és valóban példamutató jogi megoldások, mint például a nemzeti kisebbségek parlamenti képviselete. Hasonlóképpen jelentős, bár lehetne szélesebb körű, és nagyobb mértékben garanciákkal ellátva a nyelvhasználati jogok alkotmányi szabályozása. Ugyanakkor teljességgel hiányoznak az autonómiajogok, a szimbólumok használatának joga, illetve a létező vonatkozó alkotmányos rendelkezések a törvényi szabályozásokban mintha korlátozóbb értelmezést kapnának.

A nemzeti kisebbségi jogok érvényesítésének legfőbb akadálya azonban a jogalkalmazásban mutatkozik meg, ami leginkább a közhatóságok, sok esetben rosszhiszemű normaértelmezésében, a jogszabályi rendelkezések jelentésének kiforgatásában, a rendelkezés céljának mellőzésében nyilvánul meg. Ezt pedig gyakran megerősíti, illetve jogilag jóváhagyja a bírói jogértelmezés, illetve jogalkalmazás is.

Összességében azt mondhatjuk, hogy létezik egy többé-kevésbé kielégítő, de mindenképpen bővíthető, tökéletesíthető alkotmányos kerete a nemzeti kisebbségek jogi szabályozásának, ugyanakkor a törvényi keret már több hiányosságot és kivetnivalót tartalmaz, főként a nem kellően világos, nem elégséges szabályozások vagy éppen a szabályok, bizonyos törvények hiánya miatt. Itt jegyezzük meg, hogy éppen a nemzeti kisebbségek jogállásáról szóló törvény nincsen elfogadva Romániában, miközben ilyen tartalmú jogszabálynak az alkotmány rendelkezései szerint is kellene lennie, és ilyen értelmű, szabályozási tárgyú jogszabálytervezet, törvénytervezet be is lett nyújtva a parlamentnek. Az igazi gondot pedig, még a létező kisebbségi jogok érvényesítésében is a nem megfelelő, a rendelkezés célját kijátszó, a szabályozások érvényesülését akadályozó vagy éppen ellehetetlenítő, rosszhiszemű jogalkalmazás jelenti.

Ebben a létező normatív szabályozási és joggyakorlati környezetben vizsgáljuk a román alkotmánybíróság viszonyulását, vonatkozó esetgyakorlatán keresztül,

1 Példaként néhány mű az egyébként gazdag kisebbségjogi szakirodalomból: FÁBIÁN-ÖTvös 2003; FÁBiÁN-JAKAB 2015; ToRó 2016, 18-53; VARGA 2013; HORVÁtH 2009, 208-220; VERESS 2006, 35-41; KÁNTOR-MAJTÉNYi 2004.

2 Purdă-Diaconu 2016, 193-199.; Ionescu 2015, 189-232.; Demeter 2012; Andreescu 2004; JuRA 2006; NĂSTASE 1998; DiaCONu 1998, 79.

3 Ezek között említjük: ANDREescu-STAN-WeBer 1997, 154-185. Ezzel kapcsolatosan kialakult vitában megemlítjük még A Romániai Emberi Jogokat Védő Egyesület (APADOR-CH) kisebbségi koncepciója című dokumentumot, valamint ennek elemzését elvégző tanulmányt: BAKK 1997, 200-208. A tanulmány jelentősége, hogy elemez néhány alapvető fogalmat, mint a belső önrendelkezés, a nemzetállam, az autonóm közösség, az autonómia. 
a nemzeti kisebbségi kérdésekhez, a nemzeti kisebbségek alkotmányos jogainak tiszteletben tartásához és érvényesüléséhez.

\section{A nemzeti kisebbségekre vonatkozó alkotmányos rendelkezések}

Romániában az 1989-es rendszerváltást követően, az 1990. májusi általános (első szabad) választások alkalmával megalakult Parlament egyben alkotmányozó gyűlés is volt, azzal a felhatalmazással, hogy legkésőbb 1992. február végéig el kell fogadja az új alkotmány szövegét, ellenkező esetben automatikusan megszűnik a megbízatása.

A kisebbségi kérdés, úgy is mint léthelyzet, állapot, tény és mint probléma a kezdetektől fogva felmerült és jelen volt, illetve jelen van a politikai közéletben, közbeszédben, és kevésbé a politikatudományi és jogtudományi szakmai vitákban.

Összegezve, az 1991-ben elfogadott, majd 2003-ban módosított román alkotmány nemzeti kisebbségekre vonatkozó rendelkezései a legegyszerűbb, a legkézenfekvőbb kritériumok alapján két csoportba sorolhatók. Azok a rendelkezések, amelyek kifejezetten a nemzeti kisebbségekre vonatkoznak, illetve azok, amelyek közvetett módon érintik ezeket a közösségeket. Az első kategóriába tartoznak (egy további csoportosítás szerint) azok, amelyek alapelvi szabályozások, és azok, amelyek alapvető emberi jogokként jelennek meg. Hasonlóképpen a jogok köréből megkülönböztethetjük az alapjogokat és azokat a nem alapvető emberi jogoknak minősülő jogokat, jogosultságokat, amelyek államszervezeti elvekhez, a politikai közképviselet és demokrácia elveinek érvényesítéséhez köthető jogok.

A második alapcsoportba az alkotmánynak akár az összes többi rendelkezését is sorolhatnánk, de természetesen inkább csak azokról van szó, amelyeknek az általánosnál sajátosabb hatása is lehet a nemzeti kisebbségi közösségekre. Ilyenek leginkább az alapjogok, azok közül is a politikai és a polgári jogok.

$\mathrm{Az}$ áttekinthetőség érdekében a legfontosabbakat, az alkotmány cikkeit is megjelölve, az 1. táblázatban összesítettem.

Talán a táblázatból is jól kivehető, hogy a nemzeti kisebbségekre vonatkozóan, az identitáshoz való jogon túlmenően (amely jelenti az etnikai, kulturális, nyelvi és vallási identitást, ennek megőrzését, kifejezését és fejlesztését) alapjogként az anyanyelvi jogokat szabályozza, egyrészt, mint az anyanyelv elsajátításának, valamint az anyanyelven való oktatásnak a jogát, másrészt pedig az anyanyelvhasználatot szóban és írásban a helyi közigazgatásban, illetve csak szóban az igazságszolgáltatásban.

Ezenkívül pedig rendkívül jelentősnek mondható a nemzeti kisebbségek politikai képviseletének a joga, lényegében, mint pozitív diszkriminációként megvalósuló kollektív jog, amennyiben mindegyik nemzeti kisebbség (összesen 18) egy parlamenti (képviselőházi) mandátumhoz jut, a törvényben biztosított kedvezőbb feltételeknek köszönhetően. Ez nem vonatkozik a romániai magyar közösségre, ugyanis 1990 óta, minden választáson a Romániai Magyar Demokrata Szövetség a pártok számára előírt feltételeket teljesítette (anélkül, hogy egyébként politikai párt lenne), és elérte a parlamentbe bejutáshoz szükséges $5 \%$-os küszöböt. 
1. táblázat: A nemzeti kisebbségekre vonatkozó rendelkezések rendszerezése

\begin{tabular}{|c|c|c|c|}
\hline \multicolumn{3}{|c|}{$\begin{array}{l}\text { A nemzeti kisebbségekre közvetlenül vonatkozó } \\
\text { alkotmányi rendelkezések, cikkelyek és bekezdések } \\
\text { szerint }\end{array}$} & \multirow{2}{*}{\begin{tabular}{|l|}
$\begin{array}{c}\text { A nemzeti kisebbségekre közvetve } \\
\text { vonatkozó rendelkezések }\end{array}$ \\
$\begin{array}{l}\text { Alkotmányos alapelvek, alapjogok, } \\
\text { más alkotmányos rendelkezések }\end{array}$ \\
\end{tabular}} \\
\hline $\begin{array}{l}\text { Általános, alapelvi } \\
\text { szabályozások }\end{array}$ & \begin{tabular}{|l|}
$\begin{array}{l}\text { Alapvetö } \\
\text { emberi jogok }\end{array}$ \\
\end{tabular} & \begin{tabular}{|l|} 
Államszervezeti \\
elvekkel (képviselet, \\
demokrácia) \\
összefüggö jogok \\
\end{tabular} & \\
\hline $\begin{array}{l}\text { 1. (1) Románia } \\
\text { nemzetállam }\end{array}$ & $\begin{array}{l}\text { 29. (1) } \\
\text { lelkiismereti } \\
\text { szabadság }\end{array}$ & \begin{tabular}{|l|} 
62. (2) a nemzeti \\
kisebbségek parlamenti \\
képviseleti joga, pozitív \\
diszkrimináció révén \\
\end{tabular} & $\begin{array}{l}\text { 1. (3) emberi méltóság, alapjogok, } \\
\text { emberi személyiség szabad fejlődése } \\
\text { stb. mint alapvető alkotmányi értékek }\end{array}$ \\
\hline $\begin{array}{l}\text { 6. (1) identitáshoz } \\
\text { való jog }\end{array}$ & $\begin{array}{l}\text { 29. (3) } \\
\text { vallás- } \\
\text { szabadság }\end{array}$ & $\begin{array}{l}\text { 120. (2) területi, } \\
\text { közigazgatási } \\
\text { egységekben, ahol } \\
\text { jelentős arányban élnek } \\
\text { a nemzeti kisebbségek, } \\
\text { anyanyelvük } \\
\text { használatának joga } \\
\text { szóban és írásban }\end{array}$ & 8. pluralizmus, politikai pártok \\
\hline $\begin{array}{l}\text { 12. kizárólag } \\
\text { a román többségre } \\
\text { vonatkozó nemzeti } \\
\text { jelképek }\end{array}$ & $\begin{array}{l}\text { 29. (5) } \\
\text { a vallási } \\
\text { felekezetek } \\
\text { autonómiája }\end{array}$ & $\begin{array}{l}\text { 128. (2) anyanyelv } \\
\text { használatának joga } \\
\text { az igazságszolgálta- } \\
\text { tásban }\end{array}$ & 15. az alapjogok egyetemessége \\
\hline $\begin{array}{l}\text { 13. hivatalos nyelv } \\
\text { kizárólag a román }\end{array}$ & $\begin{array}{l}\text { 32. (3) } \\
\text { anyanyelvi } \\
\text { oktatás }\end{array}$ & & $\begin{array}{l}\text { 21. az igazságszolgáltatáshoz való } \\
\text { szabad hozzáférés }\end{array}$ \\
\hline 16. jogegyenlőség & $\begin{array}{l}\text { 32. (5) } \\
\text { felekezeti } \\
\text { oktatás }\end{array}$ & & $\begin{array}{l}\text { 22-28. alapvető emberi jogok } \\
\text { (élethez való jog, személyi szabadság, } \\
\text { védelemhez való jog, mozgásszabadság, } \\
\text { intim, családi és magánélet védelme, } \\
\text { állandó lakhely sérthetetlensége, } \\
\text { levelezés titkossága) }\end{array}$ \\
\hline \multirow[t]{9}{*}{$\begin{array}{l}\text { 20. emberi } \\
\text { jogokra vonatkozó } \\
\text { nemzetközi } \\
\text { szerződések, } \\
\text { elsőbbsége } \\
\end{array}$} & & & $\begin{array}{l}\text { 30. (1), (2), (3) kifejezés szabadsága, } \\
\text { cenzúra tilalma, sajtószabadság }\end{array}$ \\
\hline & & & 31. információhoz való jog \\
\hline & & & 33. kultúrához való hozzáférés joga \\
\hline & & & $\begin{array}{l}\text { 36-37. szavazati jog, megválaszthatóság } \\
\text { joga }\end{array}$ \\
\hline & & & 39. gyülekezési szabadság \\
\hline & & & 40. egyesüléshez való jog \\
\hline & & & 44. magántulajdon védelme \\
\hline & & & 45. gazdasági szabadság \\
\hline & & & $\begin{array}{l}\text { 46-50. örökösödési jog, életszínvonal, } \\
\text { család, gyermekek, fiatalok védelme, } \\
\text { fogyatékos személyek jogainak védelme }\end{array}$ \\
\hline
\end{tabular}

Forrás: a szerző szerkesztése 
Végül pedig még egy a nemzeti kisebbségek (de egyébként valamennyi román állampolgár), számára fontos rendelkezés, hogy az alapvető emberi jogokat szabályozó nemzetközi szerződések rendelkezései elsőbbséget élveznek a belső joggal szemben, amennyiben a belső törvények nem tartalmaznak kedvezőbb előírásokat.

Mindezek a rendelkezések a román alkotmányban kétségtelenül fontosak a nemzeti kisebbségek számára, ugyanakkor, egyrészt ezek a meglévő jogok mindenképpen bővíthetők, kiszélesíthetők, garanciarendszerük erősíthető, másrészt az alaptörvény egy sor egyéni és közösségi jogot (nemzeti kisebbségek szimbólumainak a használata, döntéshozatali eljárásokba való bevonásuk további formái, vagy az autonómiaformák kialakításának a lehetősége) meg sem említ.

A Romániában élő nemzeti kisebbségek mindegyike őshonos kisebbségek, és nemcsak Erdélyben, de az ország majd minden tájegységében élnek kisebb vagy nagyobb számban nemzeti kisebbségek. Erdélyben Pártiumban főként magyarok, szászok; a Bánságban svábok, szerbek, szlovákok, horvátok, bolgárok; Máramarosban ruszinok, rutének, ukránok; Dobrudzsában tatárok, törökök, oroszok, makedónok, albánok; délen bolgárok. Szétszórtan, sok helyen cigányok, kisebb létszámban zsidók, örmények, olaszok.

A nemzeti kisebbségekre vonatkozó törvényi rendelkezések leginkább az anyanyelvhasználat területén jelennek meg. Említésre méltó a tanügyi törvény, amelyik érvényben van jelenleg, de az is amelyik már hatályon kívül került, ugyanis ezek külön fejezetet szenteltek a nemzeti kisebbségek nyelvén folyó oktatásnak, és amelyeket, az alkotmánybíróság is többször vizsgált. Törvény van az anyanyelvhasználatról a helyi közigazgatásban és az igazságszolgáltatásban, és amely rendelkezések a jog gyakorlásának konkrét formáit, feltételei és módozatait írják le a vonatkozó alkotmányi rendelkezésekkel összhangban.

A hatályos jogszabályi rendszer nagy hiányossága, hogy nem született meg az elmúlt közel 30 évben a nemzeti kisebbségek jogállására vonatkozó átfogó, az autonómiajogokat is rögzítő kerettörvény, annak ellenére, hogy több kezdeményezés is létezett, és az alkotmány is tesz utalást rá.

\section{Az alkotmánybíróság szabályozása. Jogállás, kinevezés, feladat- és hatáskör}

A román alkotmánybíróságot mint intézményt, valamint az alkotmánybíráskodást, mint sajátos állami tevékenységet az alkotmány 142-148-as cikkei szabályozzák. Ezek a rendelkezések meghatározzák az $\mathrm{AB}$ főbb jellemzőit, a testületnek és a bíráknak a jogállását, hatásköreit, valamint az $\mathrm{AB}$ döntéseivel/határozataival kapcsolatos legfontosabb szabályokat.

Mindezek részletes szabályozása az alkotmánybíróság megszervezéséről és működéséről szóló 1992. évi 47-es számú törvényben található meg, amely több ízben is módosult. 


\section{Az alkotmánybíróság föbb jellemzői, jogállása}

Az alkotmánybíróság kilenc bíróból áll, akiket kilenc évre neveznek ki. A megbízatás nem hosszabbítható és nem ismételhető meg. A kinevező hatóságok a kétkamarás parlament és a köztársasági elnök, olyan módon, hogy három bírót a képviselőház, hármat a szenátus és hármat az elnök nevez ki. Az alkotmánybíróság háromévente három bíróval megújul, azaz háromévenként három bírónak lejár a kilencéves mandátuma és ez alkalommal a parlament két háza és az elnök egy-egy bírát nevez ki. Ezen alkotmányos rendelkezésnek a megvalósítása olyan módon volt lehetséges, hogy az 1992-ben megalakult alkotmánybíróság három bíróját három, további három bírót hat évre és a fennmaradó három bírót kilenc évre nevezték ki, így a folytonosság és a megújulásnak ez a módja azóta is működik. Zavart az okozhat (ami egyébként néhány esetben be is következett), ha egy-egy bíró mandátumának lejárta előtt távozik (lemond, elhalálozik) a testületből. Ilyen helyzetre vonatkozóan az a szabályozás, hogy új bírót ki lehet nevezni úgynevezett töredékmandátumra. Ha ez a „töredék” három évnél kevesebb, akkor ugyanazt a bírót ki lehet úffent nevezni immáron kilenc évre és így összesen legtöbb 11 évet lehet alkotmánybíró (két mandátum keretében), illetve ki lehet nevezni három évnél hosszabb időtartamra, maximálisan hat évre, ebben az esetben újabb mandátumot nem kaphat. A jelenlegi alkotmánybíróság összetételében mindkét helyzetre van egy-egy példa. Megjegyzendő, hogy új alkotmánybírók kinevezésére 2019 május-júniusában kell sor kerüljön, a korábbi kinevezés 2016 júliusában volt.

A román alkotmányos rendszer a kelseni típusú európai modell szerinti alkotmánybíráskodást követi.

Az alkotmánybíróság, részint a bírák kinevezése, hatáskörük, feladataik, tevékenységük tartalma, valamint e tevékenység jellemző formája miatt politikai-igazságszolgáltató jellegü. A kinevezést kimondottan politikai testületek végzik, az alkotmánybírók az alkotmányos igazságszolgáltatást valósítják meg, e tevékenységre jellemző eszközökkel, módszerekkel. A Taláros Testület jogállásának további elengedhetetlen szerves része és feltétele, hogy minden más közhatóságtól független. Nem része az igazságszolgáltató (bírói) hatalmi ágnak, ugyanakkor szabályozások nem írják elő és a román alkotmányjogi szakirodalom sem tekinti önálló hatalmi ágnak.

\section{Az alkotmánybírák kinevezése és jogállása}

Az alkotmánybírók kinevezési feltételei: felsőfokú jogi végzettség, magas szintű szakmai kompetencia, legkevesebb 18 év jogi/jogászi tevékenység, vagy a felsőfokú jogi oktatásban való részvétel.

A bírák jogállásához hozzátartozik, részint a széles körü összeférhetetlenség, ami azt jelenti, hogy semmilyen köz- vagy magántisztséget nem tölthetnek be, beleértve a párttagságot sem (mindezekről, amennyiben rendelkezett valamelyikkel, kinevezése esetén le kell mondjon). Ilyen módon a bírók függetlenek, és tisztségükből 
elmozdíthatatlanok, illetve mentelmi joggal rendelkeznek, ami vonatkozik a személyi sérthetetlenségre, és arra, hogy nem vonhatók felelősségre a tevékenységük során hozott döntéseikért, megfogalmazott álláspontjaikért. ${ }^{4}$

\section{Az alkotmánybíróság feladat- és hatásköre}

Feladat- és hatásköreit az alkotmány 146-os cikke állapítja meg. E rendelkezések alapján az alkotmánybíróság hatásköre két részből tevődik össze. Egyrészt fő tevékenysége a normakontroll, a törvények alkotmányosságának az ellenőrzése, másrészt az egyéb feladatok kategóriájában különböző alkotmányos eljárások, cselekmények normakontrollját végzi.

A törvények alkotmányosságának ellenőrzése a kelseni modellnek megfelelően kétféle lehet, úgymint előzetes és utólagos normakontroll.

Az előzetes a priori alkotmányossági ellenőrzés a parlament által elfogadott és a köztársasági elnök által még ki nem hirdetett törvényekre vonatkozik. Ez azt jelenti, hogy a parlament két háza által elfogadott törvényt meg lehet támadni, az elfogadás bejelentésétől számított öt napon belül, az erre alkotmányban rögzített jogosultak által. Ezek: a köztársasági elnök, a két házelnök, 50 képviselő vagy 25 szenátor, a kormány, a Legfelsőbb Semmítő- és Ítélőszék elnöke és a nép ügyvédje (ombudsman). Előzetes normakontroll alá vonhatók a parlament által elfogadott törvények, a nemzetközi szerződések vagy egyezmények, a parlamenti szabályzatok.

Az utólagos, a posteriori normakontroll egy hatályban lévő törvényre vonatkozik, és az alkotmányossági kifogást egy rendes bíróság előtt zajló perben lehet felvetni. Az erre jogosultak a perben részt vevő felek, az ügyész, ügyet tárgyaló bíró vagy a nép ügyvédje. Az utólagos normakontroll vonatkozhat a törvényekre, a kormány által elfogadott egyszerủ és sürgősségi törvényerejủ rendeletekre.

A román alkotmányos rendszerben nem létezik utólagos absztrakt normakontroll, ez ugyanis mindig konkrét és egy folyamatban (annak bármely fázisában) lévő perhez kötött. Hasonlóképpen nem létezik az alkotmányossági panasz intézménye sem.

Az alkotmánybíróság a normakontroll során csak megkeresésre (és nem hivatalból) jár el.

Általában, föszabály szerint az alkotmánybíróság nem vizsgál törvénytervezeteket. Ez alól két kivétel van. Az első esetben hivatalból megvizsgálja az alkotmánymódosító törvénytervezetet, abból a szempontból, hogy egyrészt a kezdeményezés sajátos feltételei tiszteletben vannak-e tartva, másrészt hogy az alkotmánymódosítás nem érinti a 152-es cikkben foglalt nem módosítható rendelkezéseket, alkotmányos elveket, értékeket. Az alkotmánymódosító törvény elfogadása után az alkotmánybíróság ismét (hivatalból) megvizsgálja a parlament által elfogadott jogszabályt mielött népszavazás erősítené azt meg. A második esetben az állampolgárok által kezdeményezett tör-

4 A kérdésről részletesebben, a román alkotmányjogi szakirodalom egyik legutóbbi kötetében: MURARU-VLĂDOIU 2019, 38-92. 
vénytervezetet vizsgálja, mégpedig a kezdeményezés eljárási szabályainak tiszteletben tartását.

A rend kedvéért és a részletes elemzés igénye nélkül, az alkotmánybíróság a következő egyéb feladatokkal rendelkezik:

a) Megoldja a közhatóságok közötti alkotmányos jellegű jogvitákat.

b) Felügyeli a Románia elnökének megválasztásával kapcsolatos eljárási szabályok betartását és igazolja a szavazás eredményét.

c) Megállapítja Románia elnöke tisztségének ideiglenes betöltését indokolttá tevő körülmények létét, és megállapításait közli a parlamenttel és a kormánnyal.

d) Tanácsadó, konzultatív jelleggel véleményezi Románia elnökének tisztségéből való felfüggesztésére irányuló javaslatot. (Ez az egyetlen olyan eset, amikor az AB határozata nem kötelező a parlamentre nézve.)

e) Felügyeli a népszavazás megszervezésével és lebonyolításával kapcsolatos eljárás betartását és igazolja a szavazás eredményeit.

f) Határoz azon panaszok tekintetében, amelyek tárgya valamely politikai párt alkotmányossága.

Ezek a feladat- és hatáskörök közvetlenül nem érintik a nemzeti kisebbséget, csak annyiban, amennyiben a jogállamiság/alkotmányosság tiszteletben tartása különösen is fontos a nemzeti közösségek számára. Az alkotmánybíróság joggyakorlatában az f) pont alkalmazása során volt olyan panasz, amikor a magyar közösség érdekképviseleti szervezetének (az RMDSZ-nek) alkotmányosságát vizsgálta.

\section{Az alkotmánybíróság aktusai és azok joghatása}

Az alkotmánybíróság hatásköreinek gyakorlása során döntéseket, határozatokat és egy esetben konzultatív jellegü véleményezést fogad el.

Döntéseket ${ }^{5}$ (használva a román terminológia tükörfordítását) fogad el az előzetes és utólagos normakontroll során, amikor megoldja a közhatóságok közötti alkotmányos természetű jogi konfliktusokat, és amikor valamely politikai párt alkotmányosságát vizsgálja.

Határozatokat hoz az elnökválasztással, az elnöki tisztség helyettesítését szükségessé tevő körülményekkel, az országos népszavazással, és a népi (állampolgári) törvénykezdeményezéssel kapcsolatos hatásköreinek gyakorlása alkalmával.

Egyetlen egy esetben pedig konzultatív véleményezést fogalmaz meg, az elnök hivatalából történő felfüggesztés esetén.

Az alkotmány 147-es cikke előírja, hogy az alkotmánybíróság határozatai (döntései) általánosan kötelezőek a Hivatalos Közlönyben történő közlésüktől, és csak a jövőre nézve érvényesek. Az általánosan kötelező (erga omnes hatás) jelleg normatív

5 Nem használom a magyar terminológia szerint talán helyesebb határozat kifejezést, mert a román alkotmánybíróság is fogad el határozatokat, de csak a konkrétan nevesített egyéb hatáskörök gyakorlása során. 
erőt ad az alkotmánybírósági döntéseknek, miközben természetesen nem tekinthetők tulajdonképpeni jogi normáknak (jogszabályoknak), valójában azonban részét képezik a formális jogforrási rendszernek. ${ }^{6}$

\section{Az alkotmánybíróságra vonatkozó egyéb adat - társadalmi megítélés}

Jogszociológiai megközelítésben megállapítható, hogy a jelenleg hivatalban lévő kilenc bíróval együtt eddig 38 bírója volt/van a román alkotmánybíróságnak. Túlnyomó részük egyetemi oktató (26), akik közül, hatan egyben parlamenti tagok is voltak, további heten parlamenti tagok voltak egyetemi oktatói státusz nélkül. Ezenkívül egy ügyvédet, két volt föügyészt, és két legfelső bírósági bírót neveztek ki alkotmánybírónak.?

Miközben időnként a médiában és az általa hangolt közvéleményben nyomatékos kritikai hangsúllyal jelenik meg az a vélemény, hogy olyanokat neveznek ki alkotmánybíráknak, akik egész életükben nem voltak rendes (karrier) bírák, ez alapvetően arról tanúskodik, hogy nem igazán értik az alkotmánybíróság rendeltetését, létezésének okát, és a jogállami rendszerben betöltött szerepét.

A tapasztalat azt mutatja, hogy a túlzott (szakmai) egyoldalúság nem tesz jót a testület munkájának. Következésképpen indokolt, ha minél változatosabb jogi pályákról, és a legkülönbözőbb jogterületekben járatos személyeket neveznek ki alkotmánybírónak. Amennyiben csak egyetemi tanárokból állna a Taláros Testület, akiknek nincs vagy csak nagyon kevés gyakorlati jogi tapasztalatuk van, ez akadályozná a felmerülő, sokszor igencsak nagy, szak- és technikai tudást igénylő problémák megértését, és a döntések túlzottan elméletiek vagy éppen politikaiak lennének.

Amennyiben pedig csak egykori bírák és ügyészek alkotnák, akkor nem értenék meg az alkotmányos politikai rendszer müködését, az alkotmányos elvek jelentőségét és a korábbi szakmai életükből hozott merevebb magatartást alkalmaznák. A román alkotmánybíróságra hosszabb ideig a „professzorok kora” volt a jellemző és az utóbbi közel 10 évben, jelentek meg a jelentős bírói, ügyészi tapasztalattal rendelkező alkotmánybírók, ami kifejezetten növeli a döntések szakmai színvonalát, bár időnként érezhető a túlzottan formális legalista és kevésbé kreatív konstitucionalista hozzáállás.

Az alkotmánybírók kinevezéséről folyamatosan van (időnként hevesebb, máskor visszafogottabb) vita, arról hogy ez túlzottan politikai jellegü, bár szinte rögeszmeszerủen épült be a közvélemény tudatába, hogy ami politikai jellegű (bármilyen, illetve bárhova történő politikai kinevezés) az szükségszerűen csak rossz, illetve el- és megvetendő lehet.

Még a jobb színvonalú, szakmai tartalmú publicisztikák is arról írnak, hogy az alkotmánybírók, politikailag alárendeltek, netán kiszolgáltatottak vagy éppen lekötelezettek.

6 Mindezekről részletesebben: Vida 2011; ToAdER-SAFta 2017, 95-366.; VArga 2019, 111-138.

7 A román alkotmánybíróság internetes oldala. Elérhető: www.ccr.ro (2019. 07. 01.) 
Az természetesen tény, hogy az alkotmánybíróság változó összetétele eredményeképpen nemcsak szakmai, de politikai előéletük is nyomot hagy az egyes döntésekben, ugyanakkor távolról sem lehet baloldali, jobboldali, kormánypárti vagy ellenzéki alkotmánybíróságról beszélni. Általában tényleges függetlensége és magas szintü szakmai hozzáállása nem forgott veszélyben, illetve érzékelhető is volt, annak ellenére, hogy voltak, és minden bizonnyal lesznek is olyan döntések, amelyeket politikailag minden bizonnyal sok kritika ér majd, vagy éppen a szakmai viták kereszttüzébe kerülnek.

Elszigetelt és szélsőségesnek mondható egy-egy vélemény szerint az alkotmánybíróságot meg kellene szüntetni, esetleg hatásköreit, az alkotmányossági ellenőrzés amerikai modellje szerint, a Legfelsőbb Bíróságra átruházni. Ennek azonban nincsen semmi realitása, hiszen ehhez jelentős alkotmánymódosításra volna szükség. Az emberek, a közvélemény túlnyomó része (már aki valamelyest is ismeri az alkotmánybíróság feladatát) elfogadja a Taláros Testület legitimitását, a jogállamiság, az alkotmányosság védelmében, megőrzésében betöltött jelentős szerepét.

Az alkotmánybíróság társadalmi megítélése összetett, felemás, időnként ellentmondásos. A társadalom túlnyomó része nem ismeri az alkotmánybíróság szerepét, feladat- és hatásköreit. Ugyanakkor, különösen az utóbbi időben kapott talán túlzott publicitás a figyelem és az érdeklődés középpontjába hozta, de leginkább érzelmi, indulati megközelítések jellemzik a közvéleményt.

A politikai, közéleti sajtó generálja ezeket, bár a szélesebb tömegekhez ez nem jut el. Az talán természetes is, hogy a döntések tartalmától függően magasztalják, (dicsérik) vagy éppen kárhoztatják (szidják) az alkotmánybíróságot.

Az utóbbi időkben (egy-két évben különösen), a politikum „rászokott” az alkotmánybíróságra, abban az értelemben, hogy túlzott mértékben, esetenként indokolatlan módon fordul ahhoz. 2018-ban látványosan megugrott az előzetes normakontroll keretében történő megkeresések száma (a 2017-ben 26-ról 2018-ban 98-ra). Ezek túlnyomó részben parlamenti (ellenzéki) és a köztársasági elnök részéről indított megkeresések voltak. Várhatóan 2019-ben, választási év lévén, ez a trend megmarad.

Jelentős mértékben megnövekedtek a közhatóságok közötti alkotmányos természetű jogi konfliktusokkal kapcsolatos megkeresések is. Ez a hatáskör önmagában is nehéz az alkotmánybíróság számára, hiszen ezek a konfliktusok mindig valamilyen mértékben politikai jellegűek is. A legfőbb közhatóságok (elnök, parlament, kormány) egyre kevesebb energiát fordítanak e konfliktusok megoldására (miközben jelentős energiákat pazarolnak a konfliktusok létrehozására), és előszeretettel fordulnak az alkotmánybírósághoz, amely nemcsak megállapítja a konfliktust, de meg is kell oldja azokat, így sok esetben egyfajta döntőbíróként jelenik meg ezekben a jogvitákban.

\section{A nemzeti kisebbségekre vonatkozó alkotmánybírósági joggyakorlat}

Elöljáróban meg kell állapítanunk, hogy a nemzeti kisebbségek jogaira, alkotmányos státuszára vonatkozó elvi jelentőségű kijelentések, megállapítások csak eseti jelleggel 
és érvénnyel születtek, amelyek az előzetes vagy utólagos normakontroll során fogalmazódtak meg. Ebből kiszűrhető egy többé-kevésbé egységes és koherens alkotmánybírósági álláspont a nemzeti kisebbségekre vonatkozóan, legalábbis néhány alapelvi szintű rendelkezés vonatkozásában, mint amilyen a román nemzetállam, [1. cikk, (1) bekezdés], a nemzeti kisebbségek identitáshoz való joga (6. cikk), valamint az anyanyelvhasználat joga az oktatásban, a helyi közigazgatásban és az igazságszolgáltatásban.

Másrészt ezek az alkotmánybírósági esetgyakorlatban megfogalmazódott álláspontok nem mentesek bizonyos ellentmondásoktól sem. A nemzetállam-fogalom már-már szakrális, de mindenképpen tabuként történő értelmezésében van egy folytonosság és következetesség, de ennek a különböző nemzeti kisebbségi jogokhoz való viszonyában már van ellentmondásosság, ami időnként a nemzeti kisebbségek elönyére, máskor hátrányára válik.

A törvényekben szabályozott kisebbségi jogok alkotmánybírósági megtámadása az éppen létező aktuálpolitikai viszonyok és helyzet függvénye, a rendelkezések megítélése pedig az alkotmánybíróság összetételétől, a tagok szakmai, emberi vagy éppen a politika által determinált hozzáállásától is függ.

Az alkotmánybírósági esetgyakorlat bemutatása során mindenképpen érdemes két nagy területet megkülönböztetni, pontosabban ezeket külön-külön elemezni. Ezek egyrészt az alkotmánymódosításokkal kapcsolatos alkotmánybírósági döntések, másrészt a különböző törvényi szintű jogszabályok (törvények és törvényerejű kormányrendeletek) kisebbségekre vonatkozó rendelkezésekkel kapcsolatos alkotmánybírósági döntései.

\section{Alkotmánymódosításokkal kapcsolatos releváns döntések}

Az 1991-es új alkotmánnyal ${ }^{8}$ kapcsolatosan értelemszerűen nem lehet alkotmánybírósági döntés, hiszen maga az új alaptörvény hozta létre ezt az intézményt, konkrétan pedig 1992-ben jött létre, miután a parlament elfogadta az 1992. évi 47-es számú törvényt ${ }^{9}$ az alkotmánybíróság megszervezéséről és működéséről.

A mindez ideig egyetlen, és egyben átfogó alkotmánymódosításra 2003-ban került sor. Ennek az alkotmánymódosításnak elsődleges célja volt Románia euroatlanti csatlakozásának jogi, alkotmányi előkészítése, olyan alkotmányos rendelkezések bevezetése (például integrációs klauzula), amely megteremti a csatlakozás alaptörvényi feltételeit.

Az alkotmányozás közel másféléves folyamatában (2002-ben kezdődött) azonban számos más kérdésben is megmutatkozott a módosítás igénye és szükségessége, végül pedig messze meghaladva az eredeti szándékot egy átfogó alkotmánymódosításra került sor.

8 Megjelent a Hivatalos Közlöny 1991. évi 233-as számában.

9 Megjelent a Hivatalos Közlöny 1992. évi 101-es számában, és újra közölve a Hivatalos Közlöny 2010. évi 807-es számában. 
Az érvényben lévő alkotmányi szabályok szerint az alkotmánybíróság az alkotmánymódosító törvény tervezetét vizsgálta és ennek nyomán hozta meg a 2003. évi 148-as számú döntését. ${ }^{10}$

A nemzeti kisebbségek jogai vonatkozásában, a legfontosabb módosítások:

1. Elfogadták a felekezeti oktatást, mint önálló oktatási formát, [32. cikk (5) bekezdés].

2. A helyi közigazgatásban az anyanyelv szóban és írásban történő használatának a joga, mindazon területi közigazgatási egységekben, amelyekben a nemzeti kisebbségekhez tartozó állampolgárok részaránya jelentős [120. cikk (2) bekezdés].

3. A nemzeti kisebbségekhez tartozó állampolgárok anyanyelvhasználatának a joga a bíróságok előtt [128. cikk (2) bekezdés].

4. Mindhárom szöveget vizsgálta, de végül is valamennyit alkotmányosnak minősítette, azaz olyannak, ami nem sérti az örökérvényességi klauzulát (152-es cikk), hiszen alkotmánymódosítás során a Taláros Testület, az eljárási szabályok tiszteletben tartása mellett, csak ezt az egy aspektust vizsgálhatja.

A felekezeti oktatás vonatkozásában az alkotmánybíróság megállapította, hogy ez nem sérti az oktatásra vonatkozó alkotmányos rendet, ugyanakkor némileg kétségbe vonja a felekezeti oktatás önálló jellegét, hiszen ez egyaránt megjelenhet az állami és a magániskolákban is. Magyarán létezhetnek magán- és állami felekezeti iskolák is. Az alkotmánybíróság szövegjavaslata az, hogy az oktatás minden fokon lehet világi vagy vallásos, ami állami vagy magániskolákban történik, a törvény feltételei között. Az alkotmánymódosító parlament nem fogadta el ezt a szövegjavaslatot és meghagyta az állami, felekezeti és magán oktatási formákat. Megjegyzendő, hogy az alkotmánymódosító tervezetek alkotmánybírósági vizsgálatában hozott döntések kötelezőek, de nem a javasolt szövegek vonatkozásában, hiszen az alkotmánybíróságnak nincsen normaszöveg-kezdeményező joga.

A helyi közigazgatásban történő nyelvhasználat vonatkozásában nem fogalmaz meg az alkotmánybíróság semmit, de a jelentős részarány fogalmába egy sajátos, a normaszöveghez nem illeszkedő okfejtésbe kezd. Eszerint abban a helyzetben, ha egy területi közigazgatási egységben a nemzeti kisebbséghez tartozó személyek részarányában jelentősen felbomolhat az egyensúly a kisebbség és az ezekben a területi közigazgatási egységekben élő román etnikumú állampolgárok között - abban az értelemben, hogy ez utóbbiak képviselői esetleg nem lesznek megválasztva a helyi tanácsokba -, az diszkriminációt hoz létre. Ez egy rendkívül jellemző gondolkodásmód, hiszen egy alkotmányos alapjog (anyanyelvhasználat) biztosítása kapcsán, mintegy nemzeti (nemzetállami) reflexként a többségi jogok védelme jelenik meg. A konkrét esetben pedig a szabályozás nem a helyi képviseletről szól, hiszen ez a demokrácia szabályai szerint kell kialakuljon. Egyébként ez az aggodalom nem jelenik meg, ha egy román többségű községben, városban néhány százaléknyi nemzeti kisebbség él

10 Megjelent a Hivatalos Közlöny 2003. évi 317-es számában. 
és a választások során nem jutnak képviselethez a helyi tanácsban. Az alkotmánybíróság megjegyzése ilyen formán irrelevánsnak bizonyult a konkrét alkotmányos normaszöveggel kapcsolatban.

Az igazságszolgáltatásban a bíróságok előtti anyanyelvhasználat vonatkozásában az alkotmánybíróság nem fogalmazott meg semmilyen észrevételt.

Megemlíthető még két sikertelen, átfogó jellegű alkotmánymódosítási kísérlet, 2011-ben és 2013-ban. Az elkészült alkotmánymódosító tervezetekkel kapcsolatosan az alkotmánybíróság egyrészt a 2011. évi 799-es döntését, ${ }^{11}$ valamint a 2014. évi 80-as döntését ${ }^{12}$ hozta meg. Maga az alkotmánymódosítás azonban egyik esetben sem fejeződött be, hiszen a parlamenti plénum vitájára sem került sor, vagy a politikai szándék hiánya vagy a korábban még létező, de időközben felbomló, megszűnő politikai többség miatt.

Ilyen értelemben erősen kérdéses, hogy ezek a döntések, illetve a bennük foglalt alkotmánybírósági megállapítások mennyiben tekinthetők érvényeseknek, rendelkeznek-e precedensértékkel, és mint ilyen, szolgálnak-e hivatkozási alapul, egyáltalán mennyiben tekinthetők az alkotmánybírósági joggyakorlat szerves részének. Ennek pedig a próbája sem történt meg, hiszen sem előzetes, sem utólagos normakontroll során maga az alkotmánybíróság nem került abba a helyzetbe, hogy hivatkozzon ezekre a döntéseire.

A két döntés valós megítélésére egy következő alkotmánymódosítási eljárás keretében kerülhet sor, amennyiben hivatkozás történik majd rájuk és ezt elfogadják-e avagy sem.

A 2011. évi 799-es döntésnek egyetlen nemzeti kisebbségekre vonatkozó megállapítása van, (maga az alkotmánymódosító kezdeményezés sem tartalmazott, csak egyetlen ilyen vonatkozású cikket), amely ugyanazt a szellemiséget tükrözi, mint az előző.

Az alkotmánymódosító tervezet javasol az identitáshoz való jogot biztosító 6-os cikkhez egy új (3) bekezdést, a következő szöveggel: „A közhatóságok konzultálni fognak a nemzeti kisebbségekhez tartozó állampolgárok szervezeteivel, mindazon döntésekkel kapcsolatosan, melyek ezek etnikai, kulturális és vallási identitása megőrzésére, fejlesztésére és kifejezésére vonatkoznak."

Az alkotmánybíróság megállapítja, hogy a javasolt rendelkezés nem sérti az örökérvényességi klauzulát, hanem éppen egy módja az identitási jog érvényesülésének. Ugyanakkor ezt nem tartja alkotmányos szintű, rangú szabályozásnak, tehát ezt törvényben kellene szabályozni. Amennyiben az alkotmányozó mégis elfogadná ezt az új rendelkezést, akkor a diszkrimináció elkerülése végett, ez a hatóságok részéről történő konzultáció történjen meg a többi román (román nemzetiségủ, tehát a többségi) állampolgár szervezeteinek irányába is.

Ez visszatérő gondolatmenet és igencsak sajátos, de jellemző logika azt tükrözi, hogy minden kisebbségi jog biztosítása a diszkrimináció veszélyét hordja magában

11 Megjelent a Hivatalos Közlöny 2011. évi 317-es számában.

12 Megjelent a Hivatalos Közlöny 2014. évi 246-os számában. 
a többség számára. Ami pedig azért képtelenség, mert ha minden kisebbségvédelmi intézkedés többségvédelmi intézkedést tesz szükségessé, akkor fogalmilag a nemzeti kisebbség mint olyan, veszélyt jelent a többségre nézve, a jogok engedményként jelennek meg, amelyek szükségessé teszik a hathatósabb többségvédelmet. A kisebbségvédelem többségvédelemmé alakul át, és hogy ez utóbbira ne legyen szükség (e logika szerint), a legjobb, ha kisebbségvédelmi rendelkezések elfogadására sem kerül sor.

2013-ban elkészült a mindezidáig legátfogóbb alkotmánymódosító kezdeményezés, amelybe jelentős, a nemzeti kisebbségekre vonatkozó rendelkezések is bekerültek. Ezek közül a legfontosabbak:

a) Az (állam)terület közigazgatási megszervezés révén községekből, városokból, megyékből és régiókból áll. Régiók korábban és jelenleg sem léteznek.

b) Törvényben el lehet ismerni hagyományos (tradicionális) zónákat (tájegység), mint a régiók közigazgatási alegységeit. Ez alatt akár a Székelyföld mint közigazgatási alegység létrehozását is lehetett volna érteni.

c) A nemzeti kisebbségek törvényes képviselői, törvényben elfogadott kisebbségi statútum alapján, létrehozhatnak saját döntési és végrehajtói szerveket identitásuk megőrzésének, fejlesztésének és kifejezésének a hatáskörével.

d) A központi és helyi hatóságok az etnikai, kulturális, nyelvi és vallási identitás megőrzésével, fejlesztésével és kifejezésével kapcsolatos döntéseiket a nemzeti kisebbségekhez tartozó állampolgárok szervezeteivel való konzultáció után hozzák meg.

e) A nemzeti kisebbségek szabadon használhatják köz- és magánszférában saját szimbólumaikat, amelyek kifejezik etnikai, kulturális, nyelvi és vallási identitásukat.

A 2013-as alkotmánymódosító kezdeményezést az alkotmánybíróság a 2014. évi 80as döntésében elemezte.

A fent említett javaslatok mindegyikét az alkotmánybíróság alkotmányellenesnek minősítette, mivel álláspontja szerint valamennyi sérti az alkotmány 152. cikkét, a megváltozhatatlansági (örökérvényességi) klauzulát.

A régió fogalmát ugyan nem utasítja el az alkotmánybíróság, de megállapítása szerint a hagyományos tájegység, mint közigazgatási alegység jogilag bizonytalan, meg nem határozott fogalmak. Kijelenti, miszerint ezek a közigazgatási egységek megkérdőjelezik a román nemzetállami jelleget. A nemzet egysége akár a tradíciók perspektívájából sem kompatibilis az ország népessége egy részének közigazgatási autonómiaként értelmezett önálló státuszának elismerésével, a hagyomány mint identitáskritérium alapján.

Hasonlóképpen az egységes nemzetállami jelleg miatt elfogadhatatlan, hogy a nemzeti kisebbségek az államtól elkülönülő döntési és végrehajtói szerveket hozzanak létre. „Románia egységes állam, és ennek lényege, hogy egyetlen politikai és jogi döntési hatalommal rendelkező intézményrendszer létezik. Etnikai alapon létrehozott döntési és végrehajtási szervek létrehozása konfúziót teremtene, a döntési és végrehajtási autonómia gondolatát, ami összeegyezhetetlen az egységes állammal. 
Mindez azt jelentené, hogy bármelyik nemzeti kisebbség létrehozhatna döntési és végrehajtási szerveket, melyek státusa és az állami szervekhez való viszonya meghatározatlan, és amelynek a következménye etnikai alapú kollektív politikai autonómia megvalósulását jelentené. Döntési végrehajtási jogkörök biztosítása a nemzeti kisebbségek vonatkozásában akár identitásukat érintő kérdésekben is privilégiumot jelent, amely sérti az állampolgárok közötti egyenlőséget. Ez az érvelési rendszer nem is tesz kísérletet a nemzeti kisebbségek autonómia-törekvéseinek megértésére, és sokkal inkább indulati jellegű, politikai tartalmú állásfoglalás, semmint jogi elemzés." ${ }^{13}$

A nemzeti kisebbségekkel való döntéshozatal előtti konzultációban, amely megjelent a 2011-es alkotmánymódosító kezdeményezésben is, az alkotmánybíróság megtartotta az akkori döntésében megfogalmazott álláspontját, miszerint ez nem alkotmányos, hanem törvényi szabályozási tárgykörbe tartozó kérdés.

Végezetül a nemzeti kisebbségek saját identitásukat kifejező szimbólumok használatának a joga szintén sérti a román nemzetállami jelleget. Az, hogy a javasolt szöveg a nemzeti szimbólumokról szóló cikkelyhez került, már önmagában is téves az alkotmánybíróság szerint, mert azt sugallja, mintha a nemzeti kisebbségek saját szimbólumai nemzeti szimbólumok (azaz a román állam nemzeti szimbólumai) lennének. „A javaslatnak a 12-es cikkben történő beillesztése, annak elfogadását jelentené, hogy a nemzeti kisebbségek saját szimbólumai, nemzeti szimbólumok, [...] ami egyéb pontosítás hiányában, úgy érthető, hogy a nemzeti kisebbségeknek opciós joguk van saját szimbólumaik és a román állam nemzeti szimbólumainak használata tekintetében." Ez az érvelés sem tekinthető túl professzionálisnak, hanem sokkal inkább emlékeztet a kirekesztő jellegű, szélsőséges politikai erőkre jellemző retorikára.

Mindezeket, ahogyan az egész döntést, többségi szavazataránnyal fogadta el az alkotmánybíróság, és az akkori magyar alkotmánybíró ezekkel kapcsolatosan különvéleményt fogalmazott meg.

\section{Törvények alkotmányossági ellenőrzése során hozott döntések}

A törvényalkotás során egy sor olyan jogszabály született meg, amelyek valamilyen formában szabályozták a nemzeti kisebbségek jogait, adott esetben éppen az alkotmányi rendelkezéseknek adtak részletesebb, konzisztensebb normatív tartalmat. Ezek jelentős részét megtámadták a Taláros Testület előtt, alkotmányossági normakontrollt kérve, akár mert túlzottnak tartják a rendelkezést (magyarán úgy vélik, túl sok jogot biztosít), avagy éppen azért, mert úgy vélik, hogy a törvényi szabályozás az alkotmányi rendelkezés szintje alá kerül, és ezért lehet alkotmányellenes.

Az alkotmánybírósági döntések teljes körủ bemutatásának igénye nélkül, mintegy példázva és jelzésszerủen ismertetem összefoglalóan azokat az általam legfontosabbnak ítélt döntéseket, amelyeket a legjellemzőbb és legtöbbször előforduló kisebbségi jogi kérdésekben hoztak.

13 FÁBIÁN-ÖTvÖs 2003. 
Ezek a döntések leginkább az anyanyelvhasználat, az anyanyelvi oktatás, az anyanyelvhasználat és az autonómia kérdésében születtek.

\section{Anyanyelvi oktatás terén született főbb alkotmánybírósági döntések}

\section{Az 1995. évi 72-es döntés ${ }^{14}$}

A parlament elfogadta az új (1989 után az első) tanügyi törvényt, amely átfogóan szabályozta az egész tanügyi oktatási rendszert. Az alkotmánybíróság előzetes normakontrollban vizsgálta a törvényt. A képviselők és szenátorok által megfogalmazott keresetek, amelyek közül az egyik a kötelező vallásoktatás bevezetését kifogásolta, a másik a nemzeti kisebbségek anyanyelvén való oktatását, elsősorban annak elégtelen, néhol diszkriminatív jellegét. A törvény kétségtelenül biztosította egy bizonyos szinten az anyanyelv elsajátítását, és az anyanyelven való oktatást az alkotmányos rendelkezéseknek megfelelően, azokat többnyire a lehető legszükebben értelmezve, de ezeket a kereset szerzői nem tartották sem elégségesnek, sem alkotmányosnak. A törvény alkotmányosságát tehát a nemzeti kisebbségek szemszögéből, azok érdekei alapján kifogásolták és a szabályozásokat elégtelennek minősítették, a másik kereset pedig éppen a többségi nemzet szemszögéből, a román nemzetállam restriktíven értelmezett koncepciója alapján bírálta a törvényt, és kérte a kérdéses rendelkezések alkotmányellenességének a megállapítását.

Az 1990-es évek első felében, és különösen törvénnyel kapcsolatos egyik legjelentősebb szakmai, de egyben szimbolikus vita arról szólt, hogy a törvény csak az elemi iskolában (1-4. osztályban) írta elő, hogy a nemzeti kisebbségek számára a román nyelv és irodalom oktatása speciális programok és tankönyvek szerint történjen, a gimnáziumi és líceumi oktatásban pedig ugyanúgy, ahogyan a román anyanyelvűeknek a román iskolákban. A románok történelme és a Románia földrajza nevű tantárgyakat szintén csak az elemi iskolákban lehetett a kisebbségek anyanyelvén tanulni, a felsőbb tagozatokon ezeket a tárgyakat már románul kell oktatni.

Összességében, az alkotmánybíróság, elemezve valamennyi kritikát az egyes cikkelyekkel kapcsolatban, a törvényt egészében, úgy, ahogy a parlament azt elfogadta, alkotmányosnak minősítette, és mint megalapozatlant elutasította a kereseteket.

\section{9. évi 114-es döntés ${ }^{15}$}

Az 1995. évi 84-es tanügyi törvény módosításáról és kiegészítéséről szóló sürgősségi kormányrendelettel, pontosabban az ezt elfogadó törvénnyel szemben kértek (parlament tagjai) előzetes normakontrollt.

A kifogásolt normaszöveg előírta, hogy az állami egyetemeken, a törvény feltételei mellett, kérésre csoportok, részlegek, kollégiumok és fakultások szervezhetők,

14 Megjelent a Hivatalos Közlöny 1995. évi 167-es számában.

15 Megjelent a Hivatalos Közlöny 1999. évi 370-es számában. 
ahol a nemzeti kisebbségek nyelvén folyik az oktatás. Ebben az esetben biztosítani kell a román nyelvủ szakterminológia elsajátítását. Kérésre, törvénnyel, multikulturális felsőfokú oktatási intézmények hozhatók létre.

A törvény elismeri a nemzeti kisebbségekhez tartozó személyek jogát, hogy saját magán felsőfokú oktatási intézményeket létesítsenek és igazgassanak.

Hasonlóképpen a törvény ösztönzi a multikulturális intézményekkel és tevékenységekkel rendelkező egyetemeket a harmonikus interetnikus együttélés, a belső és európai integráció előmozdítása érdekében. Valamennyi román nyelven vagy a nemzeti kisebbségek nyelvén szervezett oktatási formába beiratkozhat és tanulhat román állampolgár, anyanyelvétôl és az előző tanulmányai során használt nyelvtől függetlenül.

Az alkotmányossági óvás szerzői azt kifogásolták, hogy a fenti rendelkezések sértik az alkotmány 6-os cikkének (2) bekezdését, amely az identitáshoz való jog keretében a többség védelmét írja elő a kisebbségi jogokkal szemben, valamint 13-as cikkét, a román nyelv hivatalos jellegét, és hogy a normaszöveg „túllépi a vonatkozó európai ajánlások kereteit”.

Az alkotmánybíróság a döntésben megállapítja, hogy a rendelkezések valóban „bővítik a nemzeti kisebbségek számára az anyanyelvi oktatáshoz való hozzáférés lehetőségét, de mindezek nem diszkriminálják a többi román állampolgárt, hanem ellenkezőleg az a rendeltetésük hogy biztosítsák az egyenlőséget a nemzeti kisebbségekhez tartozó állampolgárok és a román nemzetiségủ állampolgárok között, az által, hogy létezik egy megfelelő oktatási intézményi keret”. A rendelkezések tehát összhangban vannak az alkotmány 6-os cikkének (2) bekezdésével, az egyenlőség és a diszkrimináció tilalmának alkotmányos elveivel. Hasonlóképpen nem megalapozott az a kritika sem, amely szerint a román nyelv használatát kizárnák ezekből az intézményekből, mivel törvényi garancia van arra, hogy ezek a multikulturális intézmények a törvény szerint fognak müködni. Bármely jövőbeni törvény esetében vélelmezett ezek alkotmányossága.

Az alkotmánybíróság megállapítja, miszerint a román mint hivatalos nyelv nem sérül, hiszen maga a törvény írja elő a szakterminológia román nyelven történő elsajátításának kötelességét. Másrészt nemzetközi egyezmények, jogszabályok megsértését sem lehet megállapítani, a Regionális és kisebbségi nyelvek európai kartája, valamint a Nemzeti kisebbségek védelméról szóló keretegyezmény nincsen Románia által ratifikálva, tehát az alkotmánybíróságnak nincsen lehetősége ezek alapján vizsgálni a jogszabály alkotmányosságát. Ugyanakkor még ezek a nemzetközi egyezmények is elöírják, hogy a nemzeti kisebbségek anyanyelvhasználata nem a többségi hivatalos nyelv rovására történik.

Összességében az alkotmánybíróság elutasította az óvást mint megalapozatlant és a kérdéses törvényi rendelkezéseket alkotmányosaknak minősítette. 


\section{1. évi 2-es döntés ${ }^{16}$}

Előzetes normakontroll keretében az alkotmánybíróság az újabb oktatási törvény alkotmányosságát vizsgálta. A törvényt több szempontból is bírálják a kereset szerzői, alapvetően azonban a nemzeti kisebbségekhez tartozó személyek oktatását illetően. Ezt pedig további két megközelítésben, nevezetesen a nemzeti kisebbségekhez tartozó személyek anyanyelvű oktatásának megszervezése, valamint a román nyelv és irodalomnak a speciális program és külön tankönyv szerinti oktatása a nemzeti kisebbségek számára.

Az oktatási intézmény szervezésével kapcsolatosan a bírálat arra vonatkozott, hogy azokban a területi-közigazgatási egységekben, ahol több oktatási intézményben a nemzeti kisebbség nyelvén folyik a tanítás, legkevesebb egy iskola önálló jogi személyként kell működjön, függetlenül a tanulók számától. Az alkotmányossági óvás megfogalmazói szerint Hargita, Kovászna, Maros, Szatmár és Bihar megyékben elöállhat az a helyzet, hogy a román nemzetiségi tanulóknak ne legyen saját iskolájuk, mivel ahhoz, hogy önálló jogi személyiséggel rendelkező iskolát létrehozzanak, legkevesebb 300 tanulóra van szükség. Ezzel szemben a nemzeti kisebbségek nyelvén működő önálló iskolával szemben a törvény nem támaszt ilyen követelményt.

Hasonlóan kifogásolták azt a rendelkezést is, amely szerint azok a nemzeti kisebbségekhez tartozó tanulók, akiknek lakhelyükön nincsen kisebbségi anyanyelvi iskolájuk és a legközelebbi hasonló iskolában tanulnak, az utazási költségeiket elszámolhatják.

Végül pedig bírálat érte azt a rendelkezést is, miszerint a nemzeti kisebbségek nyelvén folyó oktatási intézményekben az egyik igazgató kötelezően az adott nemzeti kisebbséghez tartozó oktató kell, hogy legyen.

Az alkotmánybíróság elemzését a nemzeti kisebbség fogalmának igencsak változatos meghatározásával kezdte, idézve F. Capotorti, G. Alfredsson mondhatni jogtudományi meghatározásait, az Európa Tanács Parlamenti Közgyűlésének 1134-es Ajánlását, az Emberi Jogok Egyetemes Nyilatkozatát, (26. cikk), a Polgári és Politikai Jogok Egyezségokmányát (27. cikk), a Nemzeti kisebbségek védelméről szóló keretegyezményt, amelyet Románia az 1995. évi 33-as számú törvénnyel ratifikált, valamint a Regionális és kisebbségi nyelvek európai kartáját, amit Románia a 2007. évi 282-es törvénnyel ratifikált.

Megállapítása szerint mindezek a nemzetközi normák, egyezmények, ajánlások elismerik a nemzeti kisebbségek sajátos helyzetét, ami az államok részéről sajátos magatartást tesz szükségessé.

Az alkotmánybíróság kijelenti, hogy a törvények tiszteletben kell tartsák az alkotmány valamint a nemzetközi jogi dokumentumok előírásait, amelyekben Románia részes fél, vagy akár továbbfejleszthetik azokat. A vizsgált tanügyi törvény éppen ezen rendelkezéseket ülteti életbe, és fejleszti olyan módon azokat, hogy lehetővé teszi

16 Megjelent a Hivatalos Közlöny 2011. évi 136-os számában. 
a nemzeti kisebbségekhez tartozó személyek kulturális identitásának folytonos fejlődésének biztosítását.

Sorra elemezve egyenként mindegyik kifogást megállapítja, hogy egyik sem sérti az alkotmány valamely rendelkezését, és összhangban van az idézett nemzetközi jogi szabályozásokkal, standardokkal is.

Megállapítja, hogy „a tanügyi törvény nem ír elő egyetlen kollektív jogot sem a nemzeti kisebbségek számára, csak egyéni jogokat”. Másrészt: „[E]gyetlen nemzetközi jogi okmány sem szentesít kollektív jogokat a nemzeti kisebbségek számára, a román törvényhozó pedig sohasem nyilvánította ki szándékát, hogy ezt akarná. Az, hogy léteznek speciális programok a román nyelv elsajátítására a nemzeti kisebbségek számára, ez sajátos helyzetük figyelembe vételét jelenti, azt, hogy ezeknek a személyeknek, más az anyanyelvük, mint a román. Következésképpen a nemzeti kisebbségek sajátos helyzete szükségessé tesz egy megkülönböztetett jogi bánásmódot is, annak érdekében, hogy valamennyi személy számára biztosítva legyen a minőségi oktatáshoz való hozzáférés, és a tényleges egyenlőség. [...] Nem utolsó sorban a román állam intézményeinek a kötelessége, hogy a szükséges, megfelelő óraszámban biztosítsák a román nyelv és irodalom tanulását." ${ }^{17}$

Mintegy összegzően e kérdéssel kapcsolatban pedig az alkotmánybíróság megállapítja, hogy „a nemzeti kisebbségekhez tartozó személyek joga, hogy használják az anyanyelvüket az oktatásban, a közigazgatásban és az igazságszolgáltatásban, nem sérti a román nyelv hivatalos jellegét, ahogyan azt az Alkotmány 13-as cikke előírja, és amely jelleget közvetett módon az Alkotmány 152-es cikkének (1)-es bekezdése (örökérvényességi klauzula) is biztosít." 18

Az alkotmánybíróság elutasította az alkotmányossági óvást mint megalapozatlant, és a törvényt alkotmányosnak minősítette.

\section{8. évi 118-as döntés ${ }^{19}$}

Előzetes normakontroll keretében a parlament tagjai megtámadták azt a törvényt, amely létre kívánta hozni a marosvásárhelyi II. Rákóczi Ferenc római katolikus fögimnáziumot.

Az alkotmánybíróság megalapozottnak minősítette a keresetet, ugyanis középiskola létrehozása kizárólagos hatásköre a helyi közigazgatási hatóságoknak vagy a kormánynak. Következésképpen a parlament a törvény elfogadásával megsértette egyrészt a helyi autonómiát, másrészt a hatalommegosztás alkotmányos elvét. Másrészt pedig a szabályozás egyedi (azaz nem normatív) jogszabálynak minősül, márpedig a törvényhozás csak normatív, általános jellegủ szabályozási tárgykörökben alkothat törvényt.

17 FÁBiÁN-Ötvös 2003.

18 PÉNTEK-BENő é. n. Elérhető: http://adattar.adatbank.transindex.ro/tanulmany/08_Pentek-Beno_ Nyelvi_jogok_Ro.htm (2019.07.01.)

19 Megjelent a Hivatalos Közlöny 2018. évi 367-es számában. 
A döntés $5: 4$ arányban született, a négy ellenző bíró különvéleményt fogalmazott meg, amelyben kifejtették, hogy a törvény normatív, hiszen nem egyetlen jogviszonyra vonatkozik, hanem egy sor jövőbeni jogviszonyt fog szabályozni. Egy kisebbségi középiskola létrehozása nemcsak helyi ügy, hanem országosnak is tekinthető, hiszen egy kisebbségi alapjog az anyanyelvhasználat, pontosabban a nemzeti kisebbségek anyanyelvükön való oktatása jogának érvényesítéséről, oktatási intézmény létrehozásáról van szó. Nem sérült a helyi autonómia sem, hiszen a törvényhozás csak akkor avatkozott be, amikor nyilvánvalóvá vált, hogy a helyi hatóságok nem tudják (nem akarják) létrehozni az iskolát. A helyi autonómiára hivatkozva nem csorbulhatnak alapvető emberi jogok. Végezetül a különvéleményt megfogalmazók szerint a hatalommegosztás elve sem sérült, hiszen nem vont el hatáskört a kormánytól.

Mindezek ellenére, a Taláros Testület alkotmányellenesnek minősítette a törvényt.

\section{A közhatóságok előtt történő anyanyelvhasználat vonatkozásában hozott néhány alkotmánybírósági döntés}

\section{6. évi 40-es döntés ${ }^{20}$}

Az 1991. évi 69-es számú, a helyi közigazgatásról szóló törvény néhány rendelkezését módosították. Többek között azt a rendelkezést vezette be, hogy „a nemzeti kisebbségekhez tartozó állampolgárok, akik a helyi hatóságokhoz anyanyelvükön fogalmaznak meg egy kérést, azt román nyelvű fordítással együtt kell, benyújtsák”. Ezt a kereset szerzői az anyanyelvhasználat korlátozásának minősítették és mint ilyet alkotmányellenesnek.

Az alkotmánybíróság megállapította, hogy egyrészt az állampolgárok azon lehetősége, hogy anyanyelvükön fogalmazzák meg a hatóságok irányába a kérésüket, összhangban van az alkotmány 6-os cikkének (1) bekezdésével. Az, hogy „[a] kéréshez csatolni kell annak román nyelvű fordítását nincsen ellentétben ezzel a joggal, ellenkezőleg egy lehetséges diszkriminációt előz meg, ami bekövetkezhetne a nemzeti kisebbségekhez tartozó állampolgárokkal szemben, hiszen az adott kisebbségi nyelvet nem ismerő hatóság hosszabb ideig oldaná meg a kérést, ami hátrányos lehet a kérelmező számára." Következésképpen a rendelkezés összhangban van az alkotmány 16-os cikkével, amely az állampolgárok közötti jogegyenlőséget írja elő.

Az alkotmánybíróság mint megalapozatlant elutasította a kérést és a kifogásolt törvényi rendelkezést alkotmányosnak minősítette.

\section{Az 1999. évi 113-as döntés ${ }^{21}$}

A román alkotmányos rendelkezések lehetővé teszik a delegált törvényhozást vagy másképpen a törvényhozási felhatalmazást, amelynek révén a kormány törvényerejü

20 Megjelent a Hivatalos Közlöny 1996. évi 76-os számában.

21 Megjelent a Hivatalos Közlöny 1999. évi 362-es számában. 
egyszerü vagy sürgősségi kormányrendeleteket fogadhat el. Esetünkben egyszerü kormányrendeletről van szó, amit a kormány egy a parlament által elfogadott felhatalmazási törvény alapján fogad el. Pontosabban az alkotmánybíróságot megkereső szenátorok a felhatalmazási törvényt támadták meg előzetes normakontroll keretében, amelyben azt kifogásolták, hogy a felhatalmazás alapján a kormány egyszerü rendeletben ratifikálhatja a Regionális és Kisebbségi Nyelvek Európai Kartáját. Az alkotmány a parlament számára is elöír bizonyos korlátokat arra vonatkozólag, hogy mire adhat felhatalmazást a kormánynak, hogy törvényerejű jogszabályokat alkosson. Eszerint a parlament csak egyszerű törvények tárgykörébe tartozó szabályozási kérdésekben hatalmazhatja fel a kormányt.

A kereset szerzői azt állítják, hogy a karta olyan rendelkezéseket tartalmaz, amelyek ratifikációja előtt alkotmányt kellene módosítani, hiszen a rendelkezések egy része nincsen összhangban az 1-es cikk (1) bekezdésével, miszerint „Románia nemzeti, független egységes és oszthatatlan állam”. Hasonlóképpen sérti a román nyelv hivatalos jellegére vonatkozó rendelkezést.

Az alkotmánybíróság egyrészt megállapította, hogy egy nemzetközi egyezmény ratifikációja a parlamentben egyszerű törvény szabályozási tárgykörébe tartozik, tehát adhat felhatalmazást a kormánynak egyszerü, törvényerejű kormányrendelet elfogadására.

Az, hogy a karta tartalmazna olyan rendelkezéseket, amelyek sértik az érvényben lévő alkotmányt, pontosabban olyan rendelkezések megváltoztatását tennék szükségessé, amelyek az örökérvényességi klauzula védelme alatt állnak, nem bizonyítható. A karta maga is azt írja elö, hogy a részes államok legkevesebb 35 paragrafust vagy bekezdést kell elfogadjanak, ami helyzetüknek megfelelö, következésképpen az alkotmánybíróság nem foglalhat állást egy feltételezett, hipotetikus helyzetre, hiszen nem tudhatja melyik az a 35 rendelkezés, amit a kormány elfogadna.

Az alkotmánybíróság a felhatalmazási törvényt beleértve arra vonatkozó részét, hogy a kormány ratifikálhatja a Regionális és Kisebbségi Nyelvek Európai Kartáját alkotmányosnak minősítette.

\section{6. évi 636-os döntés ${ }^{22}$}

Utólagos normakontroll keretében a Polgári eljárási törvénykönyv (Peltk.) 150-es cikke (4) bekezdésének első mondatával kapcsolatban nyújtott be alkotmányossági kifogást egy peres ügyben.

Az alkotmánybírósági megkeresést a Hargita megyei törvényszék előtt zajló jogvita felperesének kérésére a törvényszék nyújtotta be. A kifogásolt normaszöveg előírja: „Abban az esetben, amikor az iratok egy idegen nyelven vannak megszerkesztve, ezeket hitelesített másolatban kell letenni (a bíróság elé) mellékelve az iratoknak, egy hiteles fordító által készített hiteles fordítását." A megkeresés szerzője szerint a ren-

22 Megjelent a Hivatalos Közlöny 2017. évi 41-es számában. 
delkezés sérti az alkotmány 128. cikkének (3) bekezdését, amely szerint a nemzeti kisebbségekhez tartozó állampolgárok bíróságok előtti anyanyelvhasználatának módozatait, beleértve a fordító, illetve tolmács használatát, olyan módon kell megállapítani, hogy ez ne akadályozza az igazságszolgáltatás menetét és az érdekeltek terhére ne rójon többletköltségeket.

Az alkotmánybíróság abból kiindulva, hogy Romániában a hivatalos nyelv a román, vélelmezheti, hogy valamennyi állampolgár ismeri a nyelvet. A polgári perek román nyelven zajlanak, ami azt jelenti, hogy a megszólalások, a kérések, az iratok, az eljárási aktusok ezen a nyelven történnek. Ugyanakkor a nemzeti kisebbségekhez tartozó állampolgároknak jogukban áll anyanyelvükön kifejezni magukat a per során, akkor is, ha egyébként ismerik a román nyelvet, korlátozottan a peres eljárás szóbeli részében, de nem az eljárási iratok vonatkozásában, amelyek román nyelven készülnek, keletkeznek. Amennyiben nem román nyelven megfogalmazott iratokat kívánnak bemutatni a bíróság előtt, azokról hivatalos fordító által készített fordítást kell készíteni és azzal együtt beterjeszteni.

Az alkotmánybíróság mint megalapozatlant elutasította az alkotmányossági kifogást.

\section{A 2017. évi 328-as döntés ${ }^{23}$}

Az alkotmánybíróság előzetes normakontroll keretében egy olyan elfogadott, de még ki nem hirdetett törvényt vizsgál, amely kiegészít két hatályban lévő törvényt. Ezek a 2006. évi 95-ös számú törvény az egészségügyi reformról, valamint a 2011. évi 292-es számú törvény a szociális asszisztenciáról.

A kifogásolt kiegészítés az anyanyelvhasználatot bővíti az egészségügyi és szociális intézményekben, azáltal, hogy elöírja, miszerint ezeknek az intézményeknek mindazokban a területi közigazgatási egységekben (községek, városok, megyék), amelyekben a nemzeti kisebbségekhez tartozó személyek/lakosok aránya eléri a 20\%-ot vagy legkevesebb 5000 lakost, biztosítaniuk kell olyan egészségügyi, orvosi és szociális szakemberek alkalmazását, akik ismerik az adott nemzeti kisebbség nyelvét.

A szabályozás újdonsága, hogy egyrészt ezek az intézmények mindent meg kell tegyenek az említett személyzet alkalmazása érdekében, másrészt (és ez az igazi újdonság), hogy a korábban is létező $20 \%$-os küszöb mellé alternatív küszöbként bevezeti az abszolút számban kifejezett 5000 főt.

Az alkotmányossági óvást 124 képviselő nyújtotta be, miközben a törvényt egyetlen tartózkodás mellett, lényegében egyhangúlag fogadták el, és azt kifogásolták, hogy az alternatív küszöb sérti a jogegyenlőséget és diszkriminációhoz vezet, másrészt pedig a törvényszöveg nem kellően világos, pontos és előrelátható, mivel nem lehet tudni, hogy az ilyen módon alkalmazottaknak egy vagy több kisebbség nyelvét kell ismerniük.

23 Megjelent a Hivatalos Közlöny 2017. évi 424-es számában. 
Az alkotmány 128-as cikkének (2) bekezdése értelmében mindazon területi közigazgatási egységekben, amelyekben a nemzeti kisebbségek részaránya jelentős, ezek anyanyelvét lehet használni. A jelentős részarányt a törvényt 20\%-ban határozta meg. Ugyanakkor, és ezt az alkotmánybíróság a döntésben is megfogalmazta, nincsen semmilyen alkotmányi akadálya annak, hogy a törvényhozó bővítse e jogok körét vagy azok alkalmazási lehetőségét.

Következésképpen, ha egy adott területi közigazgatási egységben élő nemzeti kisebbség részaránya meghaladja a két küszöb valamelyikét, meg kell tegyenek mindent a nemzeti kisebbségekhez tartozó személyekkel való megfelelő kommunikáció biztosítása érdekében, alkalmazniuk kell az adott nyelvet ismerő szakszemélyzetet. Mondhatjuk, hogy az anyanyelvhasználat joga mellett az egészségvédelemhez való alapjognak (34. cikk) is érvényesülnie kell.

Az alkotmánybíróság azt is megállapította, hogy nyilvánvalóan valamennyi nemzeti kisebbség számára érvényes a rendelkezés amennyiben a részarányra vagy lakosságszámra vonatkozó feltételt teljesíti az adott területi közigazgatási egységben.

Végül az alkotmánybíróság felhívja a figyelmet, hogy a kifogásolt törvényes rendelkezés nemcsak a román alaptörvény rendelkezéseivel van összhangban, de a Regionális és Kisebbségi Nyelvek Európai Kartájával is, amelyet Románia aláírt és a 2007. évi 282-es számú törvénnyel ratifikált is, következésképpen az szerves része a román belső jogrendszernek.

Az alkotmánybíróság az alkotmányossági óvást mint megalapozatlant elutasította, a törvényes rendelkezések alkotmányosak.

\section{A 2018. évi 633-as döntés ${ }^{24}$}

Az alkotmánybíróság a Büntető eljárási törvénykönyv (Beltk.) és az igazságszolgáltatás megszervezéséről szóló 2004. évi 304-es törvény módosításáról és kiegészítéséről szóló törvényt vizsgálta elözetes normakontrollban.

Az amúgy nagyon terjedelmes döntés tartalmaz néhány elvi észrevételt a bíróság előtti anyanyelvhasználat jogáról. Az alkotmánybíróság megállapította: Az alkotmány 13-as cikke értelmében, Romániában a hivatalos nyelv a román nyelv. A román nyelv hivatalos jellege kötelezővé teszi ennek használatát az állampolgárok számára az állami hatóságok irányába, hiszen ezen a nyelven szerkesztik meg és hozzák a nyilvánosság tudomására valamennyi hivatalos dokumentumát a román államnak. Ezt azonban összhangba kell hozni az alkotmány 32-es cikkével, amely biztosítja a nemzeti kisebbségek jogát, hogy anyanyelvüket megtanulhassák, illetve, hogy anyanyelvükön tanuljanak, valamint az alkotmány 128 -as cikkével, amely előírja, hogy a nemzeti kisebbségekhez tartozó személyeknek joguk van, hogy anyanyelvükön fejezzék ki magukat a bíróságok előtt, tolmácsok és fordítók igénybevételével, olyan módon, hogy

24 Megjelent a Hivatalos Közöny 2018. évi 1.020-as számában. 
ez ne zavarja meg az igazságszolgáltatás megfelelő lebonyolítását. ${ }^{25}$ A továbbiakban az alkotmánybíróság megállapítja, hogy a Beltk. előírja, miszerint „a nemzeti kisebbségekhez tartozó román állampolgároknak joguk van, hogy kifejezzék magukat a bíróságok előtt, az eljárási iratokat román nyelven kell megszerkeszteni."

A módosító javaslat szerint a nyomozó hatóságnak köteles a nemzeti kisebbséghez tartozó személy számára, aki egyébként a sértett fél, annak anyanyelvén közölni bármilyen bírósági megkeresésnek az elmaradását. Az alkotmánybíróság mint alkotmányellenest elutasította ezt a szöveget, de azért, mert a mondat nem tartalmaz utalást a román nyelven szerkesztett szövegre, ami alkotmányos kötelezettsége a hatóságnak. Ugyanakkor megállapítja a Taláros Testület, hogy ez a rendelkezés, bár szélesebb, mint az alkotmány 128-as cikkében foglaltak, de nincsen vele ellentétben, a rendes törvényhozónak pedig jogában van kiszélesíteni az anyanyelv használatának jogát a bíróságok előtt.

Az alkotmánybíróság megállapítja, hogy az alkotmány nem akadályozza meg a törvényhozót, hogy megemelje a nemzeti kisebbségek védelmének standardját, arra azonban kötelezi, hogy tartsa szigorúan tiszteletben a román nemzetállam követelményeit, közöttük a román nyelvet, mint hivatalos nyelvet, az által, hogy minden eljárási iratot, amelyet a román hatóság fogad el román nyelven kell megszerkeszteni. ${ }^{26}$

\section{Az autonómia fogalmával kapcsolatos alkotmánybírósági döntések}

\section{4. évi 154-es döntés ${ }^{27}$}

Az utólagos normakontroll keretében ellenőrzött pénzügyi fiskális törvényi szabályozásokkal kapcsolatos AB döntés (egy peres ügy kapcsán, amelyben egy polgármesteri határozatot kifogásoltak, helyi adók és illetékek kiszabása vonatkozásában), csak azért tartom relevánsnak, mert az alkotmánybíróság megfogalmazza (és aztán számos más döntésében megismétli) a helyi autonómiára vonatkozó megállapítását. Eszerint: „[A] helyi autonómia elve, amit az Alkotmány 120 cikkének (1) bekezdése ír elő, nem feltételez egy teljes (totális) függetlenséget, és területi-közigazgatási egységek közhatóságainak a kizárólagos hatáskörét. A helyi hatóságok kötelesek alávetni magukat a törvényes rendelkezéseknek melyek az ország egész területére nézve érvényesek, melyek az általános, országos (nemzeti) érdekeket védik. [...] Következésképpen az Alkotmánybíróság megállapítja, hogy a helyi közigazgatási hatóságok nem rendelkeznek teljes függetlenséggel a helyi adók és illetékek kiszabása vonatkozásában sem."

25 PÉNTEK-BENő é. n. Elérhető: http://adattar.adatbank.transindex.ro/tanulmany/08_Pentek-Beno_ Nyelvi_jogok_Ro.htm (2019.07.01.)

26 PÉNTEK-BENŐ é. n. Elérhető: http://adattar.adatbank.transindex.ro/tanulmany/08_Pentek-Beno_ Nyelvi_jogok_Ro.htm (2019.07.01.)

27 Megjelent a Hivatalos Közlöny 2004. évi 466-os számában. 
A helyi autonómia korlátozott jellegére vonatkozó megállapításait az alkotmánybíróság egyéb vonatkozásokban (egyéb helyi hatáskörök gyakorlása esetében is) megismétli, lényegében ugyanezzel a tartalommal.

\section{1. évi 448-as döntés ${ }^{28}$}

Utólagos normakontroll keretében a kolozsvári ítélőtábla kérte hivatalból az alkotmányossági vizsgálatot a 2006. évi 489-es a vallásszabadságról és a felekezetek (egyházak) jogállásáról szóló törvény 26-os cikke kapcsán. A peres ügy a fellebbezési fázisban volt egy törvényszéki határozat ellen, amely elutasította az ortodox egyház által elrendelt fegyelmi intézkedések semmissé nyilvánítását.

A kifogásolt törvény 26-os cikke előírja, hogy az egyházaknak saját vallási bíráskodási szerveik lehetnek, saját statútumaik és szabályzataik alapján. Belső fegyelmi ügyekben kizárólag a kánonjogi előírások alkalmazandók. A saját bíráskodási szervek léte nem zárja ki a kihágásokra és bűncselekményekre vonatkozó törvények alkalmazását. A táblabíróság azt kifogásolja, hogy amennyiben az egyházak közhasznú jogi személyek, ahogyan ezt a törvény előírja, akkor a 26-os cikkben foglaltak egy sajátos és egyben kötelező igazgatási-fegyelmi jurisdictiót jelentenek, amit az alkotmány 21. cikkének (4) bekezdése tilt.

Az alkotmánybíróság a felekezeti autonómia vonatkozásában hivatkozik szakirodalmi megállapításokra, egyetértve azzal, hogy az egyházak autonómiája az állam és egyház különválásának következménye, mindkét entitás külön intézményekkel rendelkezik, amelyek sajátos hatásköre nem keresztezi egymást. Hivatkozik az Emberi Jogok Európai Bíróságának gyakorlatára (Lautsi vs. Olaszország, 2009), amely kimondja, hogy az államnak (ideológiailag, felekezetileg) semlegesnek kell lennie, különösen az (állami) oktatás vonatkozásában, abban, hogy az iskolai osztálytermekben ne legyenek valamely vallásfelekezet vallási szimbólumai kifüggesztve.

Az alkotmánybíróság megállapítja, hogy a vallásfelekezetek vonatkozásában az autonómia azt a képességet jelenti, hogy saját statútumaik alapján törvényeket alkossanak és vezessék az egyházat.

Egy idézett szakirodalmi megállapítás szerint a vallásfelekezetek autonómiája az egyháznak azt a természetes jogát jelenti, hogy egyoldalúan hitelveket, egyházi normákat szabjon meg és bíráskodjon, sajátos természetének megfelelően önkormányzattal rendelkezzen, függetlenül az államtól.

Az alkotmánybíróság mint megalapozatlant elutasította az alkotmányossági kifogást, a kritizált normaszöveg alkotmányos.

28 Megjelent a Hivatalos Közlöny 2011. évi 424-es számában. 


\section{Egyéb ügyekben, a nemzeti kisebbségeket érintő alkotmánybírósági döntések}

\section{4. évi 47-es döntés ${ }^{29}$}

A parlament elfogadott egy törvényt a háborús veteránok, a hadirokkantak és hadiözvegyek számára biztosított jogokról. Az előzetes normakontroll keretében az alkotmánybírósághoz megkereséssel forduló képviselők és szenátorok azt kifogásolták, hogy a törvény a juttatásokat, a jogosultságokat egy feltételhez kötötte, nevezetesen, hogy „nem harcoltak a román hadsereg ellen”. Ami azt jelenti, hogy kizárják a jogosultak köréből mindazokat, akik, „kötelezően lettek besorozva vagy mozgósítva azon román területeken, amelyek időlegesen megszállás alatt voltak 1940-1945 között (a bécsi döntés alapján), és harcoltak a román hadsereg ellen". A keresetet megfogalmazók szerint ez a megkülönböztetés diszkriminatív, mivel egyrészt ilyen alapon nem lehet megkülönböztetni a jogosultak körét (történelmi kérdésekben nem lehet a jog eszközével igazságot tenni), másrészt konkrétan csak a magyarokra vonatkozott a kizárás, a németekre, akiket a német hadseregbe soroztak és harcoltak a román hadsereg ellen már nem.

Az alkotmánybíróság alkotmányellenesnek, és hátrányos megkülönböztetésnek minősítette "a harcoltak a román hadsereg ellen” kifejezést. Az okfejtés szerint a bécsi döntést utólag semmisnek nyilvánították, vagyis olyannak ami nem is létezhetett, tehát a bécsi döntésre alapozó, annak joghatásából származó körülményből fakadóan (kötelező besorolás) egy jogosultság-megvonást ír elő egy törvény, ez pedig a semmis döntés joghatásának az elismerését jelentené. Másrészt azért diszkriminatív, mert senki sem terhelhető egy olyan kötelezettség nem teljesítésével (a besorolásnak való ellenszegülés), amely kötelezettség teljesítése lehetetlen volt.

Az alkotmánybíróság helyt adott a kifogásnak ebben a vonatkozásban és a kifogásolt cikkelyt alkotmányellenesnek minősítette.

\section{5. évi 64-es döntés ${ }^{30}$}

Előzetes normakontroll keretében vizsgált az alkotmánybíróság egy törvényt, amely határátkelési illetéket vezetett be, ideiglenes jelleggel. Ezt a parlament tagjai különböző érveket felvonultatva támadták meg, mivel álláspontjuk szerint sérti a szabad közlekedés jogát. Olyan kritika is megfogalmazódott, amely szerint a nemzeti kisebbségekhez tartozó állampolgárokat ez az intézkedés megkülönböztetett módon sújtja, hiszen akadályozza a szabad kapcsolattartást adott esetben más országban élő rokonaikkal, illetve mindazokkal, akikkel közös etnikai, kulturális, nyelvi vagy vallási identitással rendelkezik.

29 Megjelent a Hivatalos Közlöny 1994. évi 139-es számában.

30 Megjelent a Hivatalos Közlöny 1995. évi 131-es számában. 
Az alkotmánybíróság megállapítása szerint egyrészt az intézkedés alkotmányos, különösen, hogy csak ideiglenes jellegü, másrészt nincsen diszkriminatív jellege, hiszen minden állampolgárra egyformán vonatkozik. Elvi jelentőséggel állapítja meg, hogy „a nemzeti kisebbségekhez tartozó román állampolgároknak ugyanolyan kötelezettségeik vannak, mint a román nemzetiségü állampolgároknak, ha ez másképpen lenne, akkor ez a nemzeti kisebbségekhez tartozó személyek számára privilégiumok biztosítását jelentené."31

\section{A 2004. évi 53-as döntés ${ }^{32}$}

Utólagos normakontroll keretében, egy bukaresti kerületi bíróságon, egy polgári per keretében felmerült a Romániai Magyar Demokrata Szövetség feloszlatásának a kérése. A perben a Nagyrománia párt, a 2003-as évi 14-es párttörvény 55-ös cikkének alkotmányosságát kifogásolta, amely álláspontjuk szerint sérti az alkotmány 16-os cikkét az állampolgárok jogegyenlőségét és a diszkrimináció tilalmát. Azt is megjegyzik, hogy diszkrimináció történik a többi egyesület irányában, azáltal, hogy az RMDSZ részt vesz a választásokon, ami egyben azt jelenti, hogy a törvény megengedi, „hogy a szervezet tisztán politikai tevékenységet végezzen ellentétben céljaival”. A pert tárgyaló bukaresti bíróság megalapozottnak tekinti a keresetet, mivel szerinte is egyenlőtlenség keletkezik a különböző egyesületek, nem-kormányzati szervezetek között, és az RMDSZ privilegizált helyzetbe kerül tevékenysége, feladatai, szerveződése vonatkozásában.

A párttörvény 55-ös cikke elóírja, hogy a nemzeti kisebbségekhez tartozó állampolgárok szervezetei, amelyek részt vesznek a választásokon, rájuk vonatkoztatva alkalmazandók a jelen törvény előírásai, kivéve néhány rendelkezést. (A norma megjelöli azoknak a cikkeknek a számát, amelyeket nem kell alkalmazni.) Az alkotmánybíróság megállapítja, hogy a kifogás szerzői lényegében azt nehezményezik, hogy a párttörvény 55-ös cikke a választásokon szereplő kisebbségi szervezeteket a politikai pártokkal asszimilálja, és ezáltal egy speciális jogállást teremt számukra, eltérőt a többi egyesülettől és alapítványtól (nem-kormányzati szervezettől).

Az alkotmánybíróság megállapítja, hogy a kifogásolt törvényi rendelkezés nem sérti az alkotmány 16-os cikkét a jogegyenlőségről és a diszkrimináció tilalmáról, hanem éppen az esélyegyenlőség érvényesítését hivatott biztosítani, az alkotmány 4-es cikkének (2) bekezdése szerint. Másrészt a kifogásolt törvényi rendelkezést az alkotmány 62-es cikkének (2) bekezdésével is össze kell vetni, amiből egyértelműen kiderül, hogy a nemzeti kisebbségi szervezetek sajátos jogállását maga az alkotmány biztosítja, azáltal, hogy lehetővé teszi számukra a parlamenti képviseletet. Következésképpen mindazok a szervezetek, amelyek egyébként a társulási jog (alkotmány 40-es cikke) alapján jönnek létre különböző jogi helyzetben lehetnek aszerint, hogy részt vesznek vagy nem a választásokon, a törvény feltételei között. Ha pedig részt vesznek, akkor

31 FÁBIÁN-ÖTVÖS 2003.

32 Megjelent a Hivatalos Közlöny 2004. évi 240-es számában. 
az esélyegyenlőség biztosítása érdekében szükséges a politikai pártokkal azonos bánásmód.

Az alkotmánybíróság elutasítja mint megalapozatlant az alkotmányossági kifogást.

\section{4. évi 272-es döntés ${ }^{33}$}

Az alkotmánybíróság ezúttal egy politikai párttal kapcsolatos panaszt vizsgál, tehát egy rendkívül ritkán gyakorolt hatáskörben hozta meg a döntését.

Egy magánszemély panaszáról van szó, aki kétségbe vonja a Romániai Magyar Demokrata Szövetségnek (RMDSZ) mint politikai párt müködésének az alkotmányosságát. A panasztevő azt kifogásolja, pontosabban kéri, hogy tisztázni kell, hogy az RMDSZ politikai párt-e, amely részt vesz az ország politikai életében, jelölteket állít a parlamenti és helyi választásokon, annak ellenére, hogy kulturális szervezetként lett bejegyezve. Romániában a nemzeti kisebbségeknek számtalan kulturális szervezete van, mégis egyiknek sincsen olyan parlamenti és helyhatósági képviselete, mint az RMDSZ-nek - állítja a szerző. Továbbá megjegyzi, hogy az RMDSZ az állami költségvetésből szubvenciót kap úgy is, mint kulturális szervezet és mint politikai párt is.

Az alkotmánybíróság először is a kereset megengedhetőségét vizsgálta, ugyanis magánszemély nem nyújthat be ilyen jellegű panaszt annak érdekében, hogy a Taláros Testület egy politikai párt alkotmányosságát vizsgálja. Ezt csak a parlament két házának elnöke kérheti parlamenti határozat alapján, vagy a kormány.

Másrészt az alkotmánybíróság csak a politikai pártok alkotmányosságát vizsgálhatja, az RMDSZ pedig nem politikai párt, nem szerepel a politikai pártok nyilvántartásában, hanem a nem-kormányzati szervezetek országos nyilvántartásában található. A hatályos törvények értelmében nemzeti kisebbségi szervezetek (amelyek nem politikai pártok) részt vehetnek a törvény feltételei között valamennyi országos és helyi választáson. Az a körülmény, hogy a törvény a kisebbségi szervezeteket bizonyos feltételek mellett, a választások alkalmával, a politikai pártokkal azonos státuszban szabályozza, ez nem változtatja át az RMDSZ-t sem politikai párttá. Amennyiben pedig a panasztevő az érvényben lévő jogszabályokat kifogásolja, az alkotmánybíróság ismételten nem vizsgálhatja ezek alkotmányosságát, mert a panaszos nincsen abban a helyzetben, hogy az alkotmányos rendelkezéseknek megfelelően kérhesse az alkotmányossági normakontrollt.

Az alkotmánybíróság a keresetet mint megengedhetetlen elutasította.

\section{Összegzés, következtetések}

Megállapítható, mintegy sommásan, de a helyzetet reálisan értékelve, hogy nem a nemzeti kisebbségek jogai az a terület, ahol az alkotmánybíróság igazán kreatív lenne vagy aktivista módon viszonyulna az alapjogok ezen részéhez. Általában sem

33 Megjelent a Hivatalos Közlöny 2014. évi 451-es számában. 
jellemző az alkotmánybírói/alkotmánybírósági aktivizmus az alapjogok területén, hanem sokkal inkább a textualista szemlélet terjedt el. Nincsen megkülönböztetett hatáskörrel, odafigyeléssel végzett alapjogi bíráskodás, és az ennek nyomán kialakult esetgyakorlat sem. Természetesen számtalan alkotmánybírósági döntés foglalkozik a legkülönbözőbb alapvető emberi jogok értelmezésével. Jelentősnek mondható az alapjogi tesztek, különösen az arányossági teszt alkalmazása, és természetesen van jó néhány referenciaértékủ döntés is, de nagy, alapjogi kérdésekben (élethez való jog, halálbüntetés tilalma, abortusz, eutanázia, egyéni/kollektív jogok, kisebbségi jogok stb.) nem születtek komoly elméleti megalapozottságú döntések, mint ahogyan jelentős, meghatározó integrációs vagy alkotmányos identitással foglalkozó, ezeket tisztázó döntések sem.

Megítélésem szerint a két hipotézis, amelyet tanulmányom elején megfogalmaztam, elemezve a vonatkozó alkotmánybírósági döntéseket igazoltnak tekinthető.

Ugyanakkor, még ha némileg kritikai éllel fogalmaztam meg az aktivizmus hiányát, a kreativitást az alkotmánybíróság részéről, a nemzeti kisebbségek jogainak értelmezése vonatkozásában, a részletesebb elemzés után úgy látom, hogy pozitívan kell értékelnünk azt, hogy az alkotmánybíróság nem adott olyan értelmezést a kisebbségekre vonatkozó törvényi rendelkezéseknek, amelyek eltávolították volna az alkotmányi elő́rásoktól. Ez még akkor is fontos, nevezetesen a kisebbségvédelem alkotmányos kereteinek a megőrzése, ha egyébként sok esetben, az „ennél többet” a „többségvédelmi" szempontok alapján nem lehetett.

A vizsgált, de általában a nemzeti kisebbségek jogaival kapcsolatos alkotmánybírósági döntések java része a különböző tanügyi törvények kifogásolt rendelkezései kapcsán az anyanyelvi oktatással foglalkozik, rendszerint elfogadva, alkotmányosnak minősítve a törvényi rendelkezéseket. Foglalkozik továbbá az anyanyelvhasználattal az oktatáson kívül a helyi közigazgatásban és az igazságszolgáltatásban, szigorúan tiszteletben tartva és tartatva a román nyelv (kizárólagos) hivatalos jellegére vonatkozó alkotmányos előírást, és többnyire leszűkítve, mondhatni textualista, és nem aktivista módon értelmezve az alkotmány anyanyelvhasználatra vonatkozó rendelkezéseit.

Elmondható és megállapítható, hogy a nemzeti kisebbségek nyelvhasználatra vonatkozó nemzetközi jogi egyezmények rendelkezéseit tiszteletben tartja, és fontos, miszerint egy-két, leginkább utóbbi időkben hozott döntéseiben elismeri, hogy a törvényhozónak jogában van bővíteni a kisebbségi jogokat, a nemzetközi standardoknál magasabb szinten biztosítani különböző jogosítványokat. Ez azért is fontos, mert sokáig (és lényegében még ma is) a román politikai elit jelentős része a nemzeti kisebbségekre vonatkozó nemzetközi jogi szabályozásokat, mint maximumot fogják fel, holott ezek a részes államok számára a belső szabályozások minimum standardját jelentik.

Az autonómia kapcsán az alkotmány rendelkezései alapján elismeri a helyi, (közigazgatási), az egyetemi és a felekezeti autonómiákat, és mintegy alapelvként rögzíti, egyébként helyesen, hogy az autonómia nem jelent teljes önállóságot és függet- 
lenséget, hiszen tiszteletben kell tartani az ország egészére nézve szóló törvényeket. Ugyanakkor igazából, direkt módon nem fogalmazott meg elvi álláspontot a kisebbségi autonómiával, annak személyi elvű vagy területi jellegű formájával kapcsolatosan, ennek oka, pedig hogy a törvényhozás nem fogadott el ilyen értelmü törvényeket, annak ellenére, hogy be lettek nyújtva (még kormány által is) ilyen szabályozási tárgykörű jogszabálytervezetek. A parlament egyébként mind a mai napig adós a nemzeti kisebbségek jogállásáról szóló törvény elfogadásával, amelyet mint organikus jogszabálytípust, az alkotmány 73. cikke (3) bekezdésének r) pontja nevesít. Ugyanakkor ezt a helyzetet az alkotmánybíróság nem tudja szankcionálni, mivel nincsen hatásköre az alkotmányos törvényhozási mulasztást (mint amilyenben e kérdés kapcsán jelenleg is a román parlament van) megállapítani és kötelezni a törvény elfogadására.

Több alkotmánybírósági döntés visszatérő elvi megállapítása, hogy a nemzeti kisebbségek jogai nem sérthetik a többség jogait, a jogegyenlőséget, nem vezethetnek diszkriminációhoz. Természetesen ez önmagában rendben volna, bár egy alkotmánybíróságtól elvárható, hogy bármilyen alapjog esetén, így a nemzeti kisebbségi jogok esetében is a jogok címzettjeinek a szempontjából értelmezze az adott alapjogot, és nem az állam, a hatóságok vagy a nemzeti többség szemszögéből. Igaz, hogy ezt a szemléletet maga az alkotmány vezette be a 6-os cikk (2) bekezdésével, hiszen az első bekezdésben megfogalmazott nemzeti kisebbségi identitásjogok mellé rendelte a második bekezdés „többségvédelmi” rendelkezését.

\section{Felhasznált irodalom}

Andreescu, Gabriel (2004): Națiuni și minorități. Iași, Polirom.

ANDreescu, Gabriel - Stan, Valentin - Weber, Renate (1997): Tanulmány az RMDSZ felfogásáról a nemzeti kisebbségek jogait illetően. Magyar Kisebbség, 3. évf. 1-2. sz. 154-185.

BAKK Miklós (1997): A Romániai Emberi Jogokat Védő Egyesület (APADOR-CH) koncepciója. Magyar Kisebbség, 3. évf. 1-2. sz. 200-208.

Demeter, A. M. (2012): Naționalism, multiculturalism, minorități naționale. Cluj-Napoca, Institutul pentru Studierea Problemelor Minorităților Naționale.

Diaconu, I. (1998): Minoritățile: Statut - Perspective. București, Institutul Român pentru Drepturile Omului.

FÁвIÁN Gyula - JАКАв Albert Zsolt szerk. (2015): Kisebbségi identitás és önrendelkezés a globalizmusban. Bíró Gáspár emlékkönyv. Kolozsvár, Nemzeti Kisebbségkutató Intézet.

FÁBIÁN Gyula - ÖTvös Patricia (2003): Kisebbségi Jog I-II. Kolozsvár, Kom-Pres.

Horváth István (2009): Kisebbségi nyelvi jogok és kisebbségi nyelvhasználat Romániában. Magyar Kisebbség, 14. évf. 51-52. sz. 208-220.

Ionescu, Cristian (2015): Constituția României, Titlul I. Principii generale, art. 1-14, Comentarii și explicații. București, C.H. Beck.

Jura, C. (2006): Drepturile omului. drepturile minorităților naționale. București, C.H. Beck.

KÁNTOR Zoltán - MAjTÉNYi Balázs (2004): Autonómiamodellek Erdélyben - jövőkép és stratégia. Magyar Kisebbség, 9. évf. 1-2. sz.

Muraru, Ioan - VhădoIU, Nasty Marian (2019): Contencios constituțional, proceduri și teorie. Hamangiu. 
NĂSTASE, A. (1998): Drepturile persoanelor aparținând minorităților naționale în dreptul internațional. București, Regia Autonomă Monitorul Oficial.

Purdă, Nicolae - Diaconu, Nicoleta (2016): Protecția drepturilor omului. București, Universul Juridic.

TOADER, Tudorel - SAFta, Marieta (2017): Curs de contencios constituțional. București, Hamangiu.

Toró Tibor (2016): Egy helyben topogva? Kisebbségi nyelvi jogok alakulása Romániában 2008-2015 között. Magyar Kisebbség, 21. évf. 2. sz. 18-53.

VArga Attila (2013): Nyelvi jogok alkotmányos szabályozása Romániában. Pro Minoritate, 3. sz. $29-41$.

VARGA Attila (2019): Román alkotmányjog. Budapest-Kolozsvár, Forum Iuris Könyvkiadó.

VERESS Emőd (2006): Nyelvhasználati jogok a román közigazgatásban. Romániai Magyar Jogtudományi Közlöny, 2. sz. 35-41.

VIDA, Ioan (2011): Curtea Constitutionala, Justitia politicului sau politica justitiei? Bucuresti, Monitorul Oficial.

\section{Internetes források}

PÉNTEK János - Benő Attila (é. n.): Nyelvi jogok Romániában. Elérhető: http://adattar.adatbank. transindex.ro/tanulmany/08_Pentek-Beno_Nyelvi_jogok_Ro.htm (2019.07.01.)

A román alkotmánybíróság internetes oldala. Elérhető: www.ccr.ro (2019. 07. 01.)

\section{Egyéb források}

Románia Hivatalos Közlönyeinek (Monitorul Oficial) említett számai:

1991. évi 233. szám

1992. évi 101-es szám

1994. évi 139-es szám

1995. évi 131-es szám

1995. évi 167-es szám

1996. évi 76-os szám

1999. évi 362-es szám

1999. évi 370-es szám

2003. évi 317-es szám

2004. évi 240-es szám

2004. évi 466-os szám

2010. évi 807-es szám

2011. évi 136-os szám

2011. évi 317-es szám

2011. évi 424-es szám

2014. évi 246-es szám

2014. évi 451-es szám

2017. évi 41-es szám

2017. évi 424-es szám

2018. évi 367-es szám

2018. évi 1.020-as szám 